\title{
Lhx2 Is an Essential Factor for Retinal Gliogenesis and Notch Signaling
}

\author{
Jimmy de Melo, ${ }^{1}$ CCristina Zibetti, ${ }^{1}{ }^{\circledR B}$ Brian S. Clark, ${ }^{1}$ Woochang Hwang, ${ }^{2}{ }^{\circledR}$ Ana L. Miranda-Angulo, ${ }^{6}$ Jiang Qian, ${ }^{2}$ \\ and Seth Blackshaw ${ }^{1,2,3,4,5}$ \\ ${ }^{1}$ Solomon H. Snyder Department of Neuroscience, ${ }^{2}$ Department of Ophthalmology, ${ }^{3}$ Department of Neurology, ${ }^{4}$ High-Throughput Biology Center, and \\ ${ }^{5}$ Institute for Cell Engineering, Johns Hopkins University School of Medicine, Baltimore, Maryland 21205, and ${ }^{6}$ Department of Psychiatry, Universidad de \\ Antioquia, Medellin, Columbia 050010
}

Müller glia (MG) are the only glial cell type produced by the neuroepithelial progenitor cells that generate the vertebrate retina. MG are required to maintain retinal homeostasis and support the survival of retinal neurons. Furthermore, in certain vertebrate classes, MG function as adult stem cells, mediating retinal regeneration in response to injury. However, the mechanisms that regulate MG development are poorly understood because there is considerable overlap in gene expression between retinal progenitor cells and differentiated MG. We show that the LIM homeodomain transcription factor $L h x 2$ is required for the development of MG in the mouse retina. Temporally controlled knock-out studies reveal a requirement for $L h x 2$ during all stages of MG development, ranging from the proliferation of gliocompetent retinal progenitors, activation of Müller-specific gene expression, and terminal differentiation of MG morphological features. We show that Lhx2 regulates gliogenesis in part by regulating directly the expression of Notch pathway genes including Notch1, Dll1, and Dll3 and gliogenic transcription factors such as Hes $1, H e s 5$, Sox8, and Rax. Conditional knock-out of $L h x 2$ resulted in a rapid downregulation of Notch pathway genes and loss of Notch signaling. We further demonstrate that Müller gliogenesis induced by misexpression of the potently gliogenic Notch pathway transcriptional effector Hes5 requires Lhx2 expression. These results indicate that Lhx 2 not only directly regulates expression of Notch signaling pathway components, but also acts together with the gliogenic Notch pathway to drive MG specification and differentiation.

Key words: differentiation; Lhx2; Müller glia; Notch; retina

Significance Statement

Müller glia (MG) are radial glial cells located in the vertebrate retina that are essential for the function and survival of retinal neurons. We found the LIM homeodomain transcription factor Lhx2 to be expressed in both retinal progenitor cells and MG. Using conditional knock-outs, we show that $L h x 2$ is required during all stages of MG development. We also show that Lhx2 regulates directly the expression of components of the Notch signaling pathway, which promotes retinal Müller gliogenesis, as well as multiple gliogenic transcription factors. We further demonstrate that $L h x 2$ is required for Hes5-dependent gliogenesis. This study identifies $L h x 2$ as a central transcriptional regulator of both Notch-dependent and Notch-independent components of retinal gliogenesis.

\section{Introduction}

Gliogenesis in the mammalian CNS is tightly regulated by both the intrinsic gene expression profile of gliogenic progenitors and

Received Aug. 20, 2015; revised Dec. 24, 2015; accepted Jan. 13, 2016.

Author contributions: J.d.M. and S.B. designed research; J.d.M., C.Z., and B.S.C. performed research; A.L.M.-A. and J.Q. contributed unpublished reagents/analytic tools; J.d.M., C.Z., B.S.C., W.H., and S.B. analyzed data; J.d.M. and S.B. wrote the paper.

This work was supported by the National Institutes of Health (Grants R01EY020560 and R01EY017015 to S.B. and Grant F32EY024201 to B.S.C.) and the Knights Templar Pediatric Ophthalmology Foundation (J.d.M.). S.B. was a W.M. Keck Distinguished Young Scholar in Medical Research. We thank J. Nathans, S. Tole, E. Monuki, W. Yap, and members of the Blackshaw laboratory for helpful comments on the manuscript.

The authors declare no competing financial interests.

Correspondence should be addressed to Seth Blackshaw, Solomon H. Snyder Department of Neuroscience, Johns Hopkins University School of Medicine, 733 N. Broadway, Baltimore, MD 21287. E-mail: sblack@jhmi.edu. the extrinsic signals to which these cells are exposed. Although gliogenesis typically occurs during or after the final wave of neurogenesis, CNS neurons and glia originate from common progenitors (Young, 1985; Turner and Cepko, 1987; McConnell, 1995; Stiemke and Hollyfield, 1995; Okano and Temple, 2009). Notch signaling has been identified as a potent driver of glial development in multiple CNS regions (Morrison et al., 2000; Wang and Barres, 2000; Gallo and Deneen, 2014). Liganddependent activation of Notch promotes glial differentiation by activating the expression of intrinsic transcriptional effectors, 
notably the bHLH factors Hes1 and Hes5 (Kopan and Ilagan, 2009; Imayoshi and Kageyama, 2014). Interestingly, Notch signaling is also required in neural progenitor cells for multipotency, proliferation, and the generation of retinal neuronal diversity (Imayoshi and Kageyama, 2014). It is not yet fully understood how Notch function transitions from retinal progenitor cell (RPC) maintenance to proglial specification and glial differentiation. It is likewise unclear how Notch-independent intrinsic signals act to modulate the level or specificity of Notch signaling.

Retinal development closely parallels that of the broader CNS, with neurogenesis proceeding in a temporally stereotyped manner, followed by gliogenesis (Young, 1985; Turner and Cepko, 1987; Stiemke and Hollyfield, 1995). Müller glia (MG), a radial glial subtype, are the only glial cells derived from RPCs. Molecular mechanisms of MG development parallel those of CNS glia elsewhere. MG development is tightly controlled by Notch signaling and is dependent on the action of Hes5 and the Hes targets Sox8 and Sox9 (Furukawa et al., 2000; Hojo et al., 2000; Muto et al., 2009). Notch signaling also acts to sustain multipotency and proliferation in RPCs, much as it does elsewhere in the CNS (Henrique et al., 1997; Jadhav et al., 2006).

The LIM homeodomain transcription factor $L h \times 2$ is a candidate for regulating retinal gliogenesis. This gene plays a central role in regulating development in multiple CNS regions (Mangale et al., 2008; Chou et al., 2009; Shetty et al., 2013; Roy et al., 2014). It is required for development of the eye (Porter et al., 1997), where it functions to maintain neuroretinal identity (Roy et al., 2013), and is also required for neuronal competence progression (Gordon et al., 2013). Lhx2 is selectively expressed in RPCs and becomes restricted to a small fraction of amacrine cells and all MG in adulthood (Porter et al., 1997; de Melo et al., 2012). In MG, Lhx2 suppresses hypertrophic reactive gliosis under nonpathogenic conditions and is required to activate the expression of glial-derived neuroprotective factors after injury (de Melo et al., 2012).

The role of $L h \times 2$ in controlling neuronal versus glial fate selection is complex. Inactivation of $L h x 2$ in the mouse hippocampus results in premature astrocyte differentiation, whereas misexpression of $L h \times 2$ blocks astrocyte formation (Subramanian et al., 2011). These effects are spatially restricted because $L h \times 2$ inactivation in the neocortex does not promote precocious astrocyte formation. The functional role of $L h x 2$ regarding the development of retinal MG is also unclear. Putative MG were identified after conditional loss of function of $\operatorname{Lh} \times 2$ during late embryonic retinal development (Gordon et al., 2013). However, the reliance on the RPC-expressed gene Sox9 as a MG marker, the persistent expression of the proliferation marker PCNA in Sox9expressing cells, and the displacement of putative MG into the outer nuclear layer calls into question whether these cells were MG or RPCs.

In this study, we observed that $L h \times 2$ is an essential factor for the development of retinal MG. Lhx2 is expressed selectively in both late retinal progenitor cells and differentiating MG and is required for Notch pathway gene expression and Notchmediated gliogenesis. Lhx2 also binds directly cis-regulatory sequences of multiple genes that are active in retinal progenitors and differentiating MG. Knock-out experiments demonstrate that $L h \times 2$ is required for normal expression of these factors.

\section{Materials and Methods}

Animals. Timed pregnant female CD-1 mice were purchased from Charles River Laboratories and pups of either sex were used for electroporation. Female R26-stop-EYFP (stock \#006148) and Pdgfr $\alpha$-Cre (stock
\#013148) mice were purchased from the The Jackson Laboratory. Lh $x 2^{\text {lox/lox }}$ mice (obtained from Dr. Edwin Monuki, University of California, Irvine) have been described previously (Mangale et al., 2008). Lh $x 2^{\text {lox/lox }}$; Pdgfr $\alpha$-Cre;R26-stop-EYFP and Lhx $22^{+/+} ;$Pdgfr $\alpha$-Cre;R26stop-EYFP mice were bred in the laboratory and mice of either sex were used in experiments. Lhx $2^{\text {lox/lox }} G L A S T-C r e E R^{\mathrm{T} 2} ; R 26-$ stop-EYFP and Lh $\times 2^{+/+} ;$GLAST-CreER ${ }^{\mathrm{T} 2} ;$ R26-stop-EYFP mice were available in our laboratory and have been described previously (de Melo et al., 2012). Rax-CreER ${ }^{\mathrm{T} 2} ; A i 9$ (R26-stop-DsRed) mice were generated in the laboratory (Pak et al., 2014). Lhx $2^{\text {lox/lox }} ;$ Rax $-C r e E R^{\mathrm{T} 2} ; A i 9$ mice were bred in the laboratory. Mice of either sex were used for studies involving GLAST$C r e E R^{\mathrm{T} 2}$ or $\mathrm{Rax}-\mathrm{CreER}^{\mathrm{T} 2}$ transgenes. All experimental procedures were preapproved by the Institutional Animal Care and Use Committee (IACUC) of the Johns Hopkins University School of Medicine.

Cell counts. All counts were performed blindly on whole retinal sections or dissociated retinas as described previously (de Melo et al., 2012). Differences between two means were assessed by unpaired two-tailed Student's $t$ test.

ChIP. CD1 mice of either sex were euthanized at postnatal day 2 (P2) and P8 according to Johns Hopkins IACUC animal policies. ChIP was performed as described previously (Shang et al., 2000). Whole dissected retinas were dissociated in a collagenase I suspension, cross-linked in $1 \%$ formaldehyde, and quenched in $125 \mathrm{~mm}$ glycine. The extracted nuclei were sheared to produce $100-500 \mathrm{bp}$ fragments by means of probe sonication. Chromatin was immunoprecipitated with goat anti-Lhx2 (Santa Cruz Biotechnology), rabbit anti-H3K27Ac (Abcam), or the corresponding isotypic controls (Abcam); retained on agarose beads (Invitrogen; washed; and purified by organic extraction. Candidate target genes that demonstrated altered expression levels in $L h \times 2$ conditional knock-out retinas by RNA-Seq were screened for Lhx 2 consensus binding sites in evolutionarily conserved regulatory regions within $15 \mathrm{~kb}$ of the transcriptional start site. Lhx2 consensus sequences were identified by querying the JASPAR database and were derived from GSE48068 (Folgueras et al., 2013). Amplicons corresponding to cis-regulatory regions that contained putative Lhx2-binding sites, along with nearby regions that lacked these sites, were amplified from chromatin immunoprecipitated with both anti-Lhx2 and IgG by SYBR qRT-PCR (Agilent Technologies).

Electroporation. Electroporation of neonatal mice of either sex was performed at P0 as described previously (de Melo and Blackshaw, 2011). Electroporated retinas were harvested at P3 or P14 as required. DNA constructs used for electroporation in this study were as follows: pCAG-Cre [Addgene plasmid 13775, deposited by C. Cepko (Matsuda and Cepko, 2007), pCALNL-GFP (Addgene plasmid 13770, deposited by C. Cepko (Matsuda and Cepko, 2007), pCALNL-DsRed (Addgene plasmid 13769, deposited by C. Cepko (Matsuda and Cepko, 2007), pCBFRE-GFP (Addgene plasmid 17705, deposited by N. Gaiano (Mizutani et al., 2007), and pCAGIG-Hes5 (generated in our laboratory for this study)].

Immunohistochemistry, retinal dissociation, and TUNEL staining. Fluorescent immunohistochemistry was performed on cryosectioned tissue and retinal dissociates as described previously (de Melo et al., 2012). Antibodies used for fluorescent immunohistochemistry were as follows: rabbit anti- $\beta$-catenin (1:400, Ctnnb1; Sigma-Aldrich), sheep anti-Chx10 (1:200, Vsx2; Ex $\alpha$ Biologicals), mouse anti-Cralbp (1:200, Rlbp1; Thermo Scientific), rabbit anti-DsRed (1:500; Clontech Laboratories), mouse anti-Gfap (1:200; Sigma-Aldrich), goat anti-GFP (1:500; Rockland Immunochemicals), rabbit anti-GFP (1:1000; Invitrogen), mouse anti-glutamine synthase (1:200, Glul; BD Biosciences), rat anti-glycine (1:200; ImmunoSolution), mouse anti-Ki67 (1:200; BD Biosciences), rabbit anti-Lhx2 (1:1500; generated in-house with Covance), mouse anti-P27 (1:200; Invitrogen), mouse anti-Pax6 (1:200; Developmental Studies Hybridoma Bank), rabbit anti-phosphohistone H3 (1:200, PHH3; Millipore), rabbit anti-Sox9 (Millipore). Secondary antibodies used were FITC-conjugated donkey anti-goat IgG (1:500), FITCconjugated donkey anti-rabbit IgG (1:500), Texas red-conjugated donkey anti-goat IgG (1:500), Texas red-conjugated donkey anti-mouse IgG (1:500), Texas red-conjugated donkey anti-rabbit IgG (1:500), and Texas red-conjugated donkey anti-sheep IgG (1:500) (all from Jackson Immu- 
noresearch). All section immunohistochemical data shown were imaged and photographed on a Zeiss Meta 510 LSM confocal microscope.

In situ hybridization. Single color in situ hybridization was performed as described previously (Blackshaw et al., 2004). Sequences for RNA probes targeting Rax and Fgf15 have been described previously (Shimogori et al., 2010). RNA probes were generated using the following EST sequences as templates: Dll3 (GenBank accession \#AW492425), Fgf15 (GenBank accession \#BE952015), Hes5 (GenBank accession \#AW244376), Lhx5 (GenBank accession \#BE943600), Notch1 (GenBank accession \#BE981557), Otp (GenBank accession \#Y10413), Rax (GenBank accession \#BC058757), Sfrp2 (GenBank accession \#AI851596), and Vsx2 (GenBank accession \#BF461223). Dll1, Lhx2, and Sox8 probe templates were amplified from retinal cDNA. The sequences of these primers were as follows (listed $5^{\prime}$ to $3^{\prime}$ ): Dll1, 5' -GTACTGCACTGACCCAATC, $3^{\prime}$-GGTTATCTGAACATCGTC CTC; $L h x 2,5^{\prime}$-ACCATGCCGTCCATCAGC, $3^{\prime}$-GGCGTTGTAAGCTGC CAG; and Sox8, 5'-AGTACCCGCATCTCCATAA, 3'-GGGCAAGTACT GGTCAAAT.

$q R T-P C R$. qRT-PCR was performed on P0 RNA isolated from $L h \times 2^{\text {lox/lox }}$; Pdgfr $\alpha$-Cre and $L h \times 2^{+/+}$; Pdgfr $\alpha$-Cre mouse retinas obtained from mice of either sex using a SYBR Green PCR Master Mix (Applied Biosystems). Primer sets for genes examined are as follows: Dll1, Forward primer GAC CTCGCAACAGAAAACCCA, Reverse Primer TTCTCCGTAGTAGT GCTCGTC; Dll3, Forward primer CTGGTGTCTTCGAGCTACAAAT, Reverse primer TGCTCCGTATAGACCGGGAC; Fgf15, Forward primer ATGGCGAGAAAGTGGAACGG, Reverse primer CTGACACAGACT GGGATTGCT; Gapdh, Forward primer AGGTCGGTGTGAACGGA TTTG, Reverse primer TGTAGACCATGTAGTTGAGGTCA; Hes1, Forward primer CCAGCCAGTGTCAACACGA, Reverse primer AAT GCCGGGAGCTATCTTTCT; Hes5, Forward primer AGTCCCAAG GAGAAAAACCGA, Reverse primer GCTGTGTTTCAGGTAGCTGAC; Notch, Forward primer CCCTTGCTCTGCCTAACGC, Reverse primer GGAGTCCTGGCATCGTTGG; Rax, Forward primer TGGGCTTTAC CAAGGAAGACG, Reverse primer GGTAGCAGGGCCTAGTAGCTT; Sox8, Forward primer AATGCCTTCATGGTGTGG, Reverse primer GC CTTGGCTGGTATTTGT; $V s x 2$, Forward primer CTGAGCAAGCCC AAATCCGA, Reverse primer CGCAGCTAACAAATGCCCAG.

RNA sequencing. RNA-Seq was performed in collaboration with the Johns Hopkins School of Medicine Deep Sequencing and Microarray Core Facility. RNA was extracted using RNeasy kits (Qiagen, Hilden, Germany) from 3 biological replicates each of $P d g f r \alpha-C r e ; L h x 2^{\text {lox/lox }}$ and $P d g f r \alpha$-Cre; $L h \times 2^{+1+}$ mice of either sex. Libraries were prepared using Illumina TruSeq RNA Sample kit (Illumina) following manufacturer's recommended procedure. The PCR amplified library was purified using RNAClean XP magnetic beads (Agencourt, Beverley, MA) and run out on a High Sensitivity DNA Chip (Agilent, Santa Clara, CA) for quality check. We used STAR (Dobin et al., 2013) to align RNA-Seq reads onto Ensembl mouse genome GRCm38, release 72 . To generate the stand attribute for alignments containing splice junctions, we used the outSAMstrandField intronMotif program. The spliced alignments without strand definition were removed. Number of reads mapped to exons was counted by htseq-count (Anders et al., 2015). Genes expressed at very low levels were omitted from further analysis. Gene expression differences between wild-type and mutant samples, significance ( $\mathrm{p}$-value) and false discovery rate (FDR) were computed using the generalized linear models based EdgeR (Robinson et al., 2010). Cellular expression data for retinal genes was compiled from the literature, relying heavily on large-scale gene expression profiling studies (Blackshaw et al., 2001; Blackshaw et al., 2004; Siegert et al., 2012; Macosko et al., 2015). All data generated from RNA-Seq studies including raw unprocessed datasets have been deposited into the Gene Expression Omnibus repository of the NCBI and have been released publicly under the series entry accession \#GSE75889.

\section{Results}

\section{Lhx 2 is required for MG development}

Lhx2 is selectively expressed in MG and a subset of amacrine cells in adult retina (Fig. 1). Ocular Lhx2 RNA expression has been reported as early as embryonic day (E)8.5, with Lhx2 expression maintained in embryonic RPCs (Porter et al., 1997; Gordon et al., 2013). Consistent with published reports, we detect Lhx2 protein in the developing eye by E10 (Fig. 1a). Lhx2 is downregulated in neuronal populations, but continues to mark mitotic progenitors (Fig. $1 f, g$, yellow arrowheads, $k, l$ ) as well as a small cohort of amacrine cells in the postnatal retina (Fig. $1 f-j$, white arrows; de Melo et al., 2012; Balasubramanian et al., 2014). Lhx2 expression in the medial inner nuclear layer (INL) of the retina is restricted to MG by postnatal day (P)7 (Fig. $1 h-j$, red arrowheads, $m-o$ ), confirming an unbroken temporal sequence of Lhx2 expression from early optic cup progenitors to MG.

To remove $L h x 2$ from developing MG, we used the platelet derived growth factor receptor $\alpha$ (Pdgfr $\alpha)$-Cre mouse line, which has been previously reported to be selectively active in both late stage retinal progenitor cells and MG (Roesch et al., 2008, Rattner et al., 2013). We crossed Pdgfr $\alpha$-Cre mice with the R26-stop-EYFP reporter line to confirm Cre activity in developing MG (Fig. 1p-u). Expression of the Cre reporter was observed in retinal progenitor cells at both $\mathrm{P} 0$ and P4. At P21, MG labeled by P27 Kip1, Glul, Rlbp1, and Lhx2 coexpressed the YFP reporter, with $97.6 \%(\mathrm{SE}=0.33 \% ; \mathrm{N}=4)$ of P2 $7^{\text {Kip } 1}$ expressing MG colabeled with YFP (Fig. $1 r-v$ ).

We bred the Pdgfr $\alpha$-Cre;R26-stop-EYFP mice to $L h \times 2^{\text {lox/lox }}$ mice to generate Pdgfr $\alpha$-Cre;R26-stop-EYFP;Lh $x 2^{\text {lox/lox }}$ knock-out animals. Adult Pdgfr $\alpha$-Cre;R26-stop-EYFP;Lhx $2^{\text {lox/lox }}$ mice displayed a loss of MG, as evidenced by the dramatic reduction in YFP-labeled radial cells in the INL and a decrease in P27 ${ }^{\text {Kip1 }}$, Glul, Rlbp1, and Sox9 expression in the INL (Fig. 2a-h). Pdgfr $\alpha$-Cre;R26-stop-EYFP; $L h \times 2^{\text {lox/lox }}$ animals also featured extensive tissue dysplasia in the outer nuclear layer (ONL) of the retina. Some degree of mosaicism was observed in Lhx2 deletion. Occasional widely spaced domains of Lhx2-positive MG were observed. These were closely correlated with normal lamination and lack of dysplasia (Fig. 2i,j). A significant decrease in the number of YFP-labeled cells was observed as early as P0 (Fig. $2 k, l$ ). Correspondingly, we observed a cell-autonomous reduction in expression of the proliferation marker Ki67 among YFPlabeled Lhx2-deficient RPCs, but not in YFP-negative RPCs (Fig. $2 m, n)$. Furthermore we identified a trend toward increased cell cell death among YFP-positive cells in Pdgfr $\alpha$-Cre;R26-stop-EYFP; $L h \times 2^{\text {lox/lox }}$ retinas, although this did not reach statistical significance (Fig. 2o).

To confirm that the loss of MG was due to cell-autonomous loss of function of $L h \times 2$, we performed mosaic loss of function experiments by electroporation of pCAG-Cre into P0 Lhx $2^{\text {lox/lox }}$ mice (Fig. 3). These experiments resulted in a selective and significant loss of MG among electroporated cells as determined by loss of the MG selective markers P2 ${ }^{\text {Kip1 }}$, Glul, Rlbp1, and Sox9 (Fig. $3 a-i$ ). The number of cells expressing MG markers was unchanged among the nonelectroporated fraction (Fig. 3j). Furthermore, electroporation of pCAG-Cre did not significantly affect the proportions of bipolar cells, amacrine cells (total fraction), glycinergic amacrine cells (late-born subset), or photoreceptors. Quantification of cell death among the electroporated cell fraction did not detect a significant increase in apoptosis (Fig. $3 k$ ). Areas of the retina with high electroporation efficiency showed focal disruptions in the integrity of the ONL concurrent with MG loss and displacement of photoreceptor soma into the photoreceptor outer segment layer (Fig. $3 b, d, f, h$, arrows). The disruption of ONL integrity was reminiscent of, though less severe than the ONL dysplasia seen in the Pdgfr $\alpha$-Cre;Lh $x 2^{\text {lox/lox }}$ mice. 

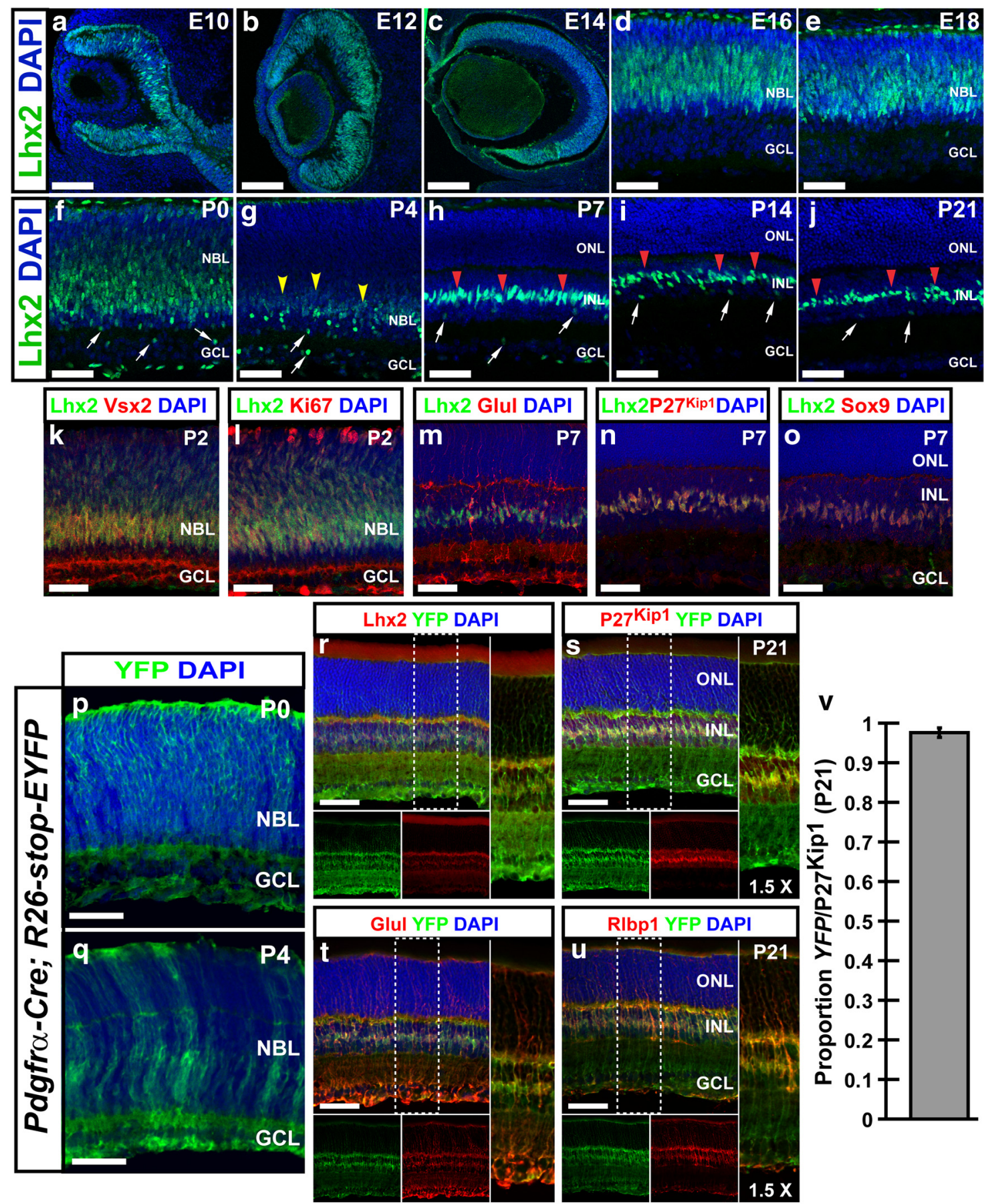

Figure 1. Expression pattern of endogenous Lhx2 and the Pdgfr $\alpha$-Cre transgene during retinal development. $\boldsymbol{a}-\boldsymbol{j}$, Immunohistochemistry demonstrating expression of Lhx2 during retinal development. $\boldsymbol{a}, \boldsymbol{b}$, Lhx2 is expressed throughout the retinal neuroepithelium and the retinal pigment epithelium at E10 and E12, but not in the lens or extraocular mesenchyme. The weak fluorescence in the lens at E12 represents nonspecific and extra-nuclear background staining. $c$, Expression of $L$ hx 2 is downregulated from newly generated retinal ganglion cells and amacrine cells by E14. $\boldsymbol{d}, \boldsymbol{e}$, Lhx2 expression continues to be downregulated by newborn neurons as retinogenesis progresses from E16 to E18. $\boldsymbol{f}, \boldsymbol{g}, \boldsymbol{k}, \boldsymbol{I}$, In postnatal retina, Lhx2 is expressed in remaining mitotic

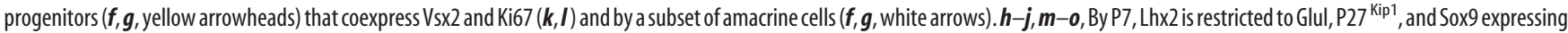
MG $(\boldsymbol{h}-\boldsymbol{j}$, red arrowheads, $\boldsymbol{m}-\boldsymbol{0})$ and a small subset of amacrine cells ( $\boldsymbol{h}-\boldsymbol{j}$, white arrows). $\boldsymbol{p}, \boldsymbol{q}$, The $P$ dgfr $\alpha$-Cre transgene is expressed in a subset of retinal progenitor cells at $P 0$ and $P 4$ in the retina. $\boldsymbol{r}$-u, Pdgfr $\alpha$-Cre; R26-stop-YFP labels MG, which express the MG markers Lhx2, P27 Kip1, Glul, and Rlbp1 at P21. $\boldsymbol{v}, 97.6 \%(\mathrm{SE}=0.33 \% ; n=4)$ of P27 Kip1 expressing MG are colabeled with YFP, demonstrating Pdgfr $\alpha$-Cre activation in MG. GCL, Ganglion cell layer; INL, inner nuclear layer; NBL, neuroblastic layer; ONL, outer nuclear layer; E, embryonic day. $1.5 \times$ digital enlargements without DAPI labeling are included for P21 data. Scale bars, $150 \mu \mathrm{m}(\boldsymbol{a}), 175 \mu \mathrm{m}(\boldsymbol{b}), 200 \mu \mathrm{m}(\boldsymbol{c}), 50 \mu \mathrm{m}(\boldsymbol{d}-\boldsymbol{u})$.

Lhx2 is required for terminal differentiation of MG

We next investigated the role of $L h x 2$ during differentiation of MG committed precursors. To address this, we generated conditional MG-specific Lhx2 knock-out mice using either Rax$C r e E R^{\mathrm{T} 2}$ or Glast-CreER ${ }^{\mathrm{T} 2}$. Induction of Rax-CreER ${ }^{\mathrm{T} 2}$ with 4-hydroxytamoxifen (4-OHTx) from P1-P3 activates Cre in MGcommitted precursors (Pak et al., 2014), while induction of GlastCreER ${ }^{\mathrm{T} 2}$ from P4-P8 activates Cre in differentiated MG. We pulsed Rax-CreER ${ }^{\mathrm{T} 2} ; \mathrm{Ai9} ; \mathrm{Lh} \times 2^{+/+}$mice with 4-OHTx daily from P1-P3 to verify Cre activity in MG. Expression of the R26-CAG- 

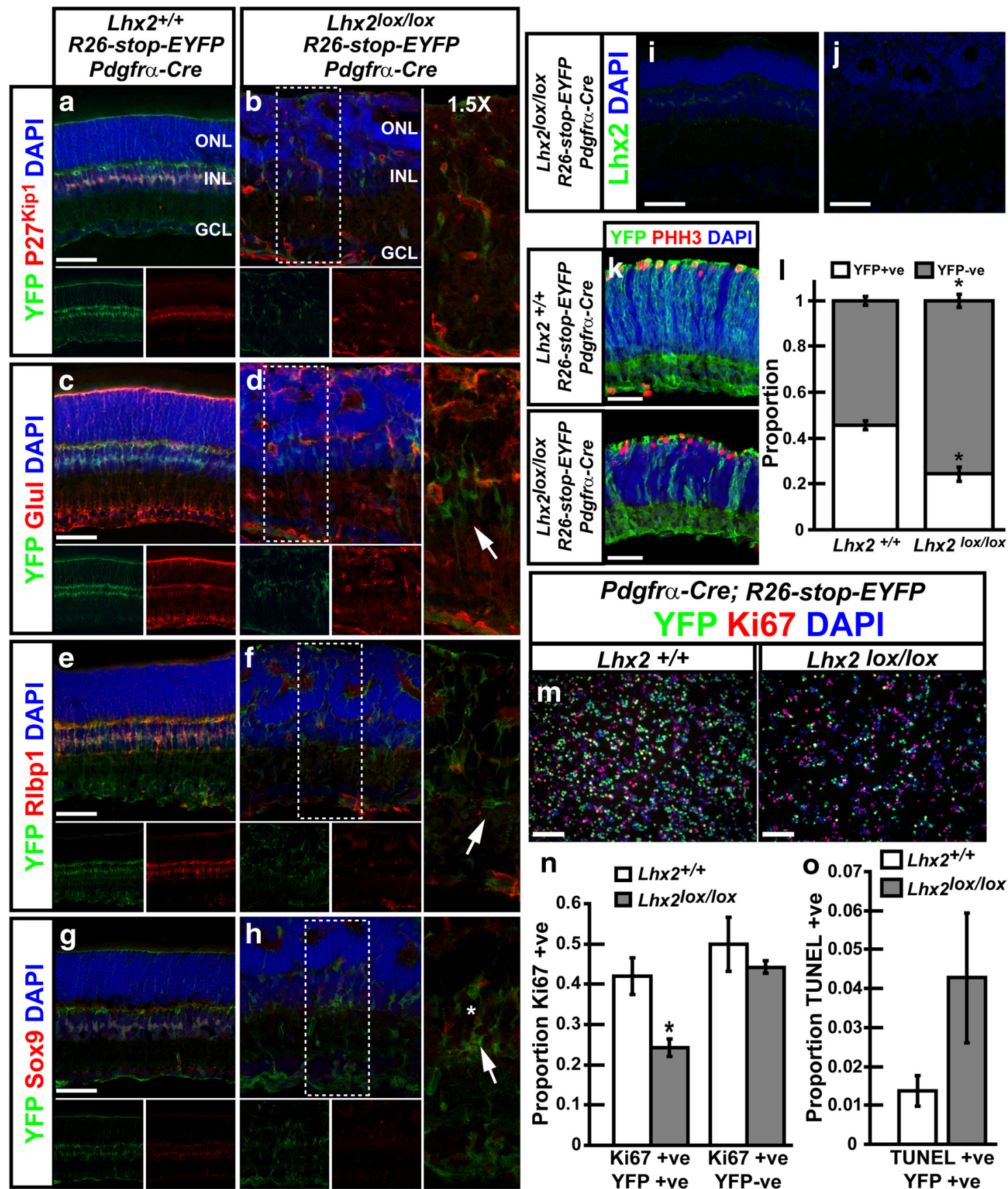

Figure 2. Retinal loss of function of $L h \times 2$ disrupts MG development. $\boldsymbol{a}-\boldsymbol{h}, P d g f r \alpha$-Cre-mediated $L h \times 2$ loss of function results in the loss of $Y F P{ }^{+} M G$ and severe retinal dysplasia by $P 30 . \boldsymbol{b}, \boldsymbol{d}, \boldsymbol{f}$, arrows, Staining of the MG markers P27 ${ }^{\text {Kip1 }}$, Glul, and Rlbp1 is lost among the remaining YFP-labeled cells in the medial INL in the Pdgfr $\alpha$-Cre; R26-stop-YFP;Lhx $2^{\text {lox/lox }}$ animals, whereas Sox9 expression is reduced but not completely lost ( $\boldsymbol{h}$, arrows, asterisk). $\boldsymbol{i}, \boldsymbol{j}$, Identification of regions of normal histology correlates with failed Lhx2 loss of function and persistent Lhx2 expression. $\boldsymbol{k}$, Immunohistochemistry showing YFP and phosphohistone H3 (PHH3) colabeling at PO in Pdgfr $\alpha$-Cre;R26-stop-YFP; Lhx $^{+/+}$and Pdgfr $\alpha$-Cre; R26-stop-YFP; $L$ hx $2^{\text {lox/lox }}$ animals. I, There is a significant $(p<0.05)$ reduction of YFP-labeled cells in Pdgfr $\alpha$-Cre; $R 26$-stop-YFP; $L h \times 2^{\text {lox/lox }}$ animals, $24.2 \%$ (SE $\left.=2.45 \%, n=4\right)$ compared with controls Pdgfr $\alpha$-Cre; $R 26$-stop-YFP; Lhx $2^{+/+}, 45.7 \%$ $(\mathrm{SE}=1.15 \%, n=4)$ at PO. $\boldsymbol{m}$, Retinal dissociates showing YFP and Ki67 colabeling at PO in Pdgfr $\alpha$-Cre; R26-stop-YFP; Lhx $2^{+/+}$and Pdgfr $\alpha$-Cre;R26-stop-YFP; Lhx $2^{\text {lox } / \text { lox }}$ animals. $n$, There is a significant $(p<0.05)$ reduction of YFP-labeled cells coexpressing Ki67 in Pdgfr $\alpha$-Cre;R26-stop-YFP;Lhx $2^{\text {lox/lox }}$ animals, $24.2 \%(S E=1.81 \%, n=4)$ compared with $42 \%(S E=4.28 \%, n=4)$ in controls at P0. No significant proportional change in coexpression of Ki67 in YFP-ve cells in conditional knock-outs compared with controls was seen (o). The number of TUNEL/YFP-labeled apoptotic cells in Pdgfr $\alpha$-Cre;R26YFP; Lhx ${ }^{\text {lox/lox }}$ animals is elevated at P0 but not statistically significant $(n>0.05)(\boldsymbol{n})$. ${ }^{*}$ Significant change by two-tailed Student's $t$ test. $1.5 \times$ digital enlargements without DAPI labeling are included for $\boldsymbol{b}, \boldsymbol{d}, \boldsymbol{f}$, and $\boldsymbol{h}$. Scale bars: $50 \mu \mathrm{m}(\boldsymbol{a}, \boldsymbol{c}, \boldsymbol{e}, \boldsymbol{g}, \boldsymbol{i}-\boldsymbol{k}), 100 \mu \mathrm{m}(\boldsymbol{m})$.

stop-DsRed reporter (Ai9) was detected in MG, which coexpressed the MG markers $\mathrm{P} 27^{\mathrm{Kip} 1}$ and Glul, but not inVsx2 labeled bipolar cells (Fig. 4a). Glast-CreER ${ }^{\mathrm{T} 2} ; R 26$-stop-YFP;Lhx2 $2^{+/+}$ mice were treated with 4-OHTx daily from P4-P8 to verify the MG expression of Glast-CreER ${ }^{\mathrm{T} 2}$. Cre activity in differentiated
MG was confirmed by colocalization of the YFP reporter with P27 ${ }^{\text {Kip1 }}$, Glul, and Rlbp1 (Fig. 4b).

Knock-out of Lhx2 in Glast-CreER ${ }^{\mathrm{T} 2} ; \operatorname{Lh} \times 2^{\text {lox/lox }}$ mice resulted in dramatic upregulation of the intermediate filament Gfap, indicative of reactive gliosis. However, both $\mathrm{MG}$ and overall retinal 


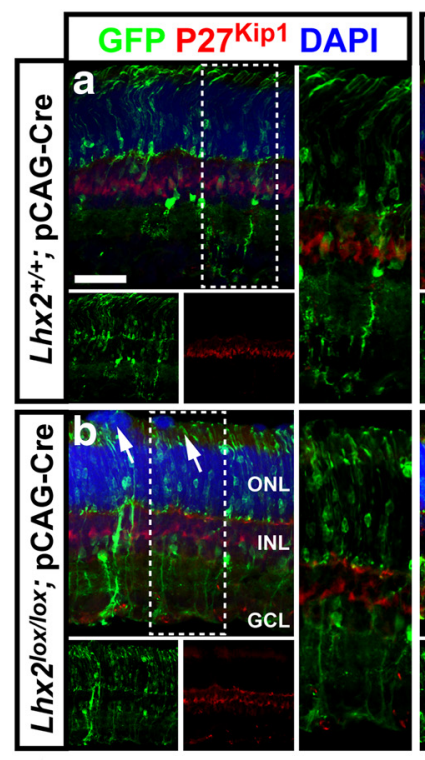

$\mathbf{I}_{0.07}$ 口pCAG-Cre; $L$ h $\times 2^{+/+}$
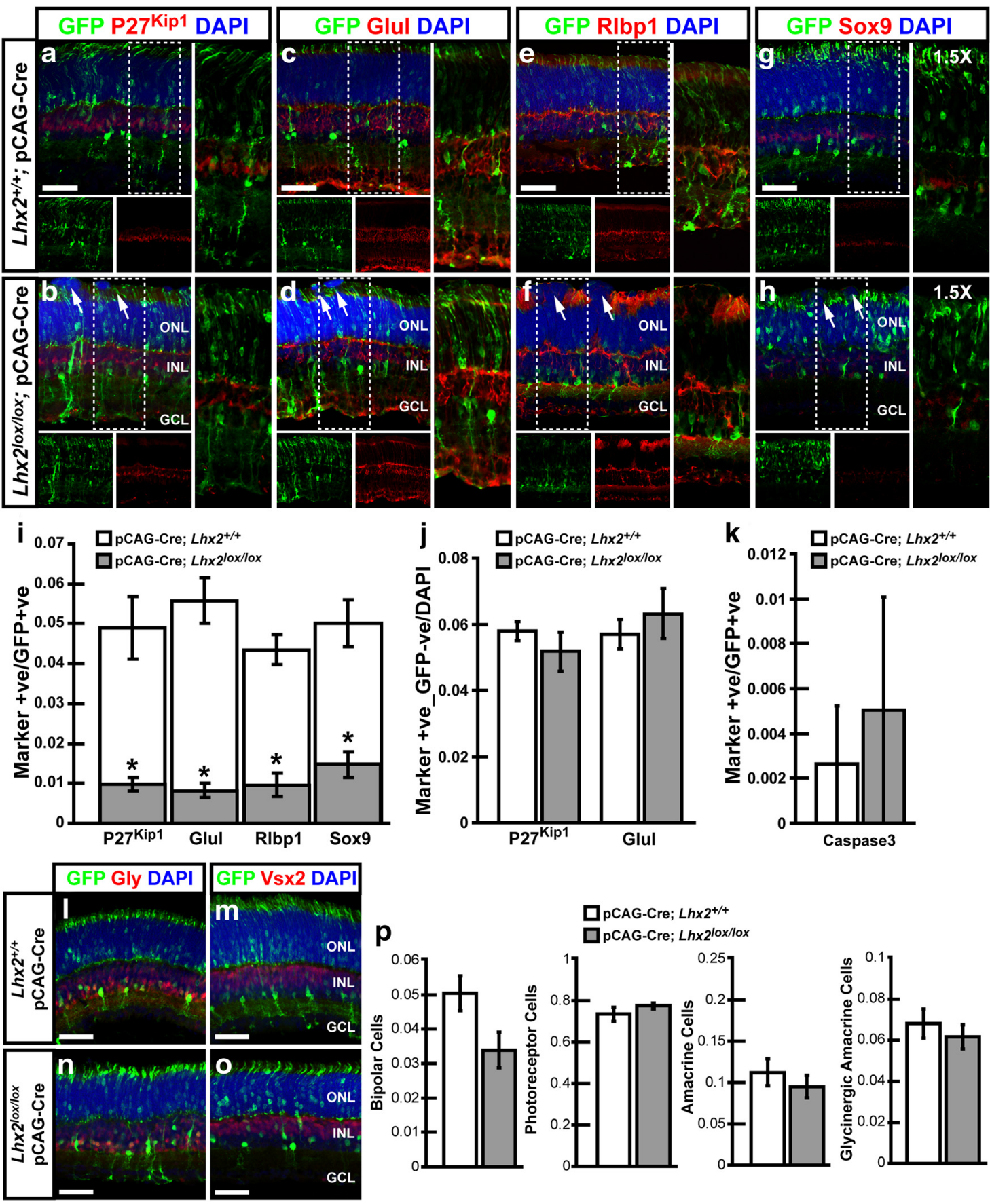

k

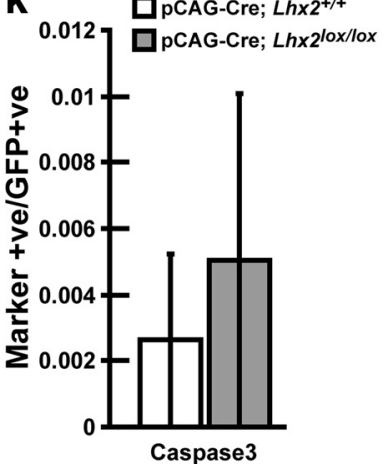

Figure 3. Mosaic loss of function of $L h x 2$ by electroporation disrupts MG development. $\boldsymbol{a}-\boldsymbol{h}$. Electroporation of $p C A G-C$ re into $L h \times 2^{\text {lox } / \text { lox }}$ mice at PO disrupts the development of MG as shown by multiple molecular markers. Regions of high electroporation efficiency show $0 \mathrm{NL}$ dysplasia $\left(\boldsymbol{b}, \boldsymbol{d}, \boldsymbol{f}, \boldsymbol{h}\right.$, white arrows). $\boldsymbol{i}$, The proportion of electroporated cells expressing the MG markers P27 Kip1 ${ }^{\text {G Glul, }}$ Rlbp1, and Sox9 is significantly $(p<0.05, n=6)$ decreased from $4.9 \%, 5.6 \%, 4.4 \%$, and $5 \%$, respectively, in $L$ hx $2^{+/+}$to $0.98 \%, 0.82 \%, 1 \%$, and $1.5 \%$, respectively, in $L h \times 2^{\text {lox/lox }}$ retinas. $j_{\text {, No }}$ change was detected in the proportion of MG generated among nonelectroporated cells (P27 ${ }^{\text {Kip1 }}$ or Glul ${ }^{+}$GFP ${ }^{+} /$DAPI). $\boldsymbol{k}$, We detected no significant increase in cell death by activated caspase-3 labeling $(p>0.05, n=3) . I-p$, There was no significant change in the fraction of bipolar cells (identified by Vsx2 expression), photoreceptors (identified by morphology), amacrine cells (identified by Pax6 expression and morphology), or the glycinergic amacrine cell subset (identified by glycine expression and morphology) after electroporation of pCAG-Cre into control or $L$ Lx ${ }^{\text {lox/lox }}$ retinas. *Statistical significance. $1.5 \times$ digital enlargements without DAPI labeling are included for $\boldsymbol{a}-\boldsymbol{h}$. Scale bars, $50 \mu \mathrm{m}(\boldsymbol{a}, \boldsymbol{c}, \boldsymbol{e}, \boldsymbol{g}, \boldsymbol{l}-\boldsymbol{o})$.

morphology in Glast-CreER ${ }^{\mathrm{T} 2} ; \mathrm{Lh} \times 2^{\mathrm{lox} / \mathrm{lox}}$ mice was grossly normal (Fig. 4c). This phenotype is identical to that seen after GlastCreER ${ }^{\mathrm{T} 2}$-mediated knock-out of Lhx2 in adult (P21) MG (de Melo et al., 2012). In contrast, Rax-CreER ${ }^{\mathrm{T} 2} ; \operatorname{Lh} x 2^{\text {lox/lox }}$ mice showed major alterations in MG marker expression as well as MG and retinal morphology (Figs. $4 d-h, 5 a$ ). MG in Rax-CreER ${ }^{\mathrm{T} 2}$; Lhx $2^{\text {lox/lox }}$ mice robustly expressed Gfap, much like what was observed in Glast-CreER ${ }^{\mathrm{T} 2} ; \operatorname{Lh} x 2^{\mathrm{lox} / \mathrm{lox}}$ mice. However, the la- beled MG were tortuous (Fig. 4d), their apical processes extended into the photoreceptor outer segment layer (Figs. $4 d$, arrows, 5a) and failed to correctly terminate at the outer limiting membrane (OLM), a morphological hallmark of differentiated MG (Reichenbach, 1989). Rax-CreER ${ }^{\mathrm{T} 2} ; \operatorname{Lh} \times 2^{\text {lox/lox }}$ mice showed decreased expression of the MG markers Rlbp1 and Glul (Fig. $4 e-h)$. Rlbp1 expression was notably reduced at the outer plexiform layer and at the apical OLM (Fig. 4e,f, arrows). Glul expres- 

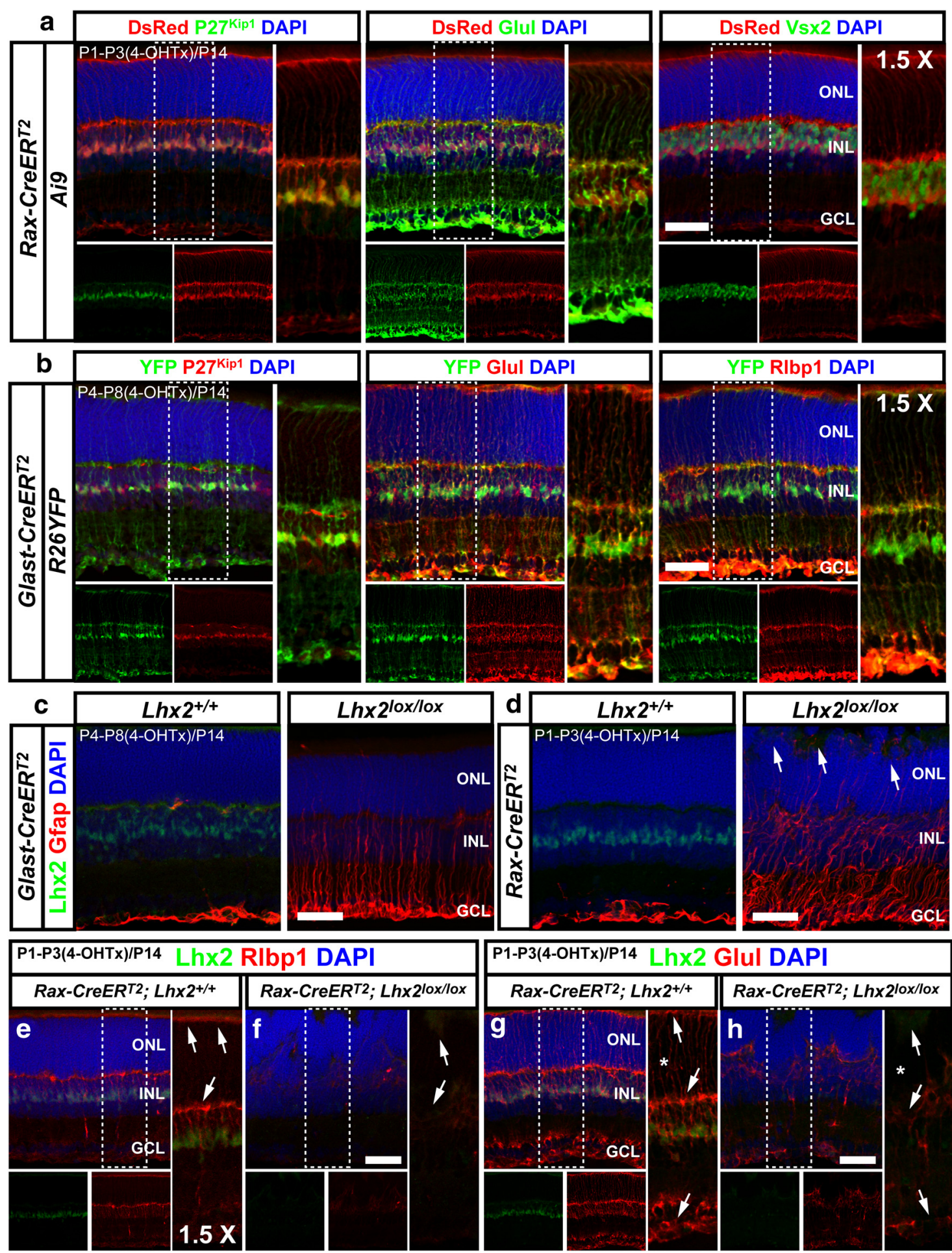

Figure 4. Conditional loss of function of $L h x 2$ in $M G$ results in specific deficits in $M G$ differentiation and/or reactive gliosis. $\boldsymbol{a}$, Conditional activation of the Rax-CreER ${ }^{T 2}$ transgene by intraperitoneal administration of tamoxifen from $\mathrm{P} 1$ to $\mathrm{P} 3$ shows that Cre expression is restricted to MG precursors. $\boldsymbol{b}$, Activation of the Glast-CreER ${ }^{\mathrm{T2}}$ transgene by intraperitoneal administration of tamoxifen from P4-P8 showing that Cre expression is restricted to MG. $c$, Glast-CreER ${ }^{T 2}$-mediated Lhx2 loss of function resulted in upregulation of Gfap expression but no changes in morphology. $\boldsymbol{d}$, Rax-CreER ${ }^{T 2}$-mediated $L h x 2$ loss of function in MG precursors results in dysmorphic MG at P14, upregulation of Gfap, and retinal dysplasia (d, arrows). $\boldsymbol{e}-\boldsymbol{h}$, Rax-CreER ${ }^{\mathrm{T} 2}$-mediated Lhx2 loss of function results in decreased expression of the MG markers RIbp 1 (e, $\boldsymbol{f}$, arrows) and Glul ( $\boldsymbol{g}, \boldsymbol{h}$, arrows, asterisks). $1.5 \times$ digital enlargements without DAPI labeling are included for $\boldsymbol{a}, \boldsymbol{b}$, and $\boldsymbol{e}-\boldsymbol{h}$. Scale bars, $50 \mu \mathrm{m}$ (all panels).

sion was also notably reduced at these regions (Fig. $4 g, h$, arrows), and could not be easily distinguished in apical MG processes (Fig. $4 g, h$, asterisks), in contrast to controls. Closer analysis revealed a failure to form normal apical OLM adherens junctions that coexpressed Ctnnb1 (also known as $\beta$-catenin), which contrasted with MG in Glast-CreER ${ }^{\mathrm{T} 2} ; \mathrm{Lh} x 2^{\text {lox/lox }}$ knock-outs that showed normal apical structures, despite the extensive Gfap activation indicative of gliosis (Fig. $5 a-c$ ). Rax-CreER ${ }^{\mathrm{T} 2} ; \operatorname{Lh} \times 2^{\text {lox/lox }}$ knockout retinas showed significant dysplasia of the ONL (Fig. $4 d$, arrows). This ONL dysplasia was again reminiscent of, but milder 

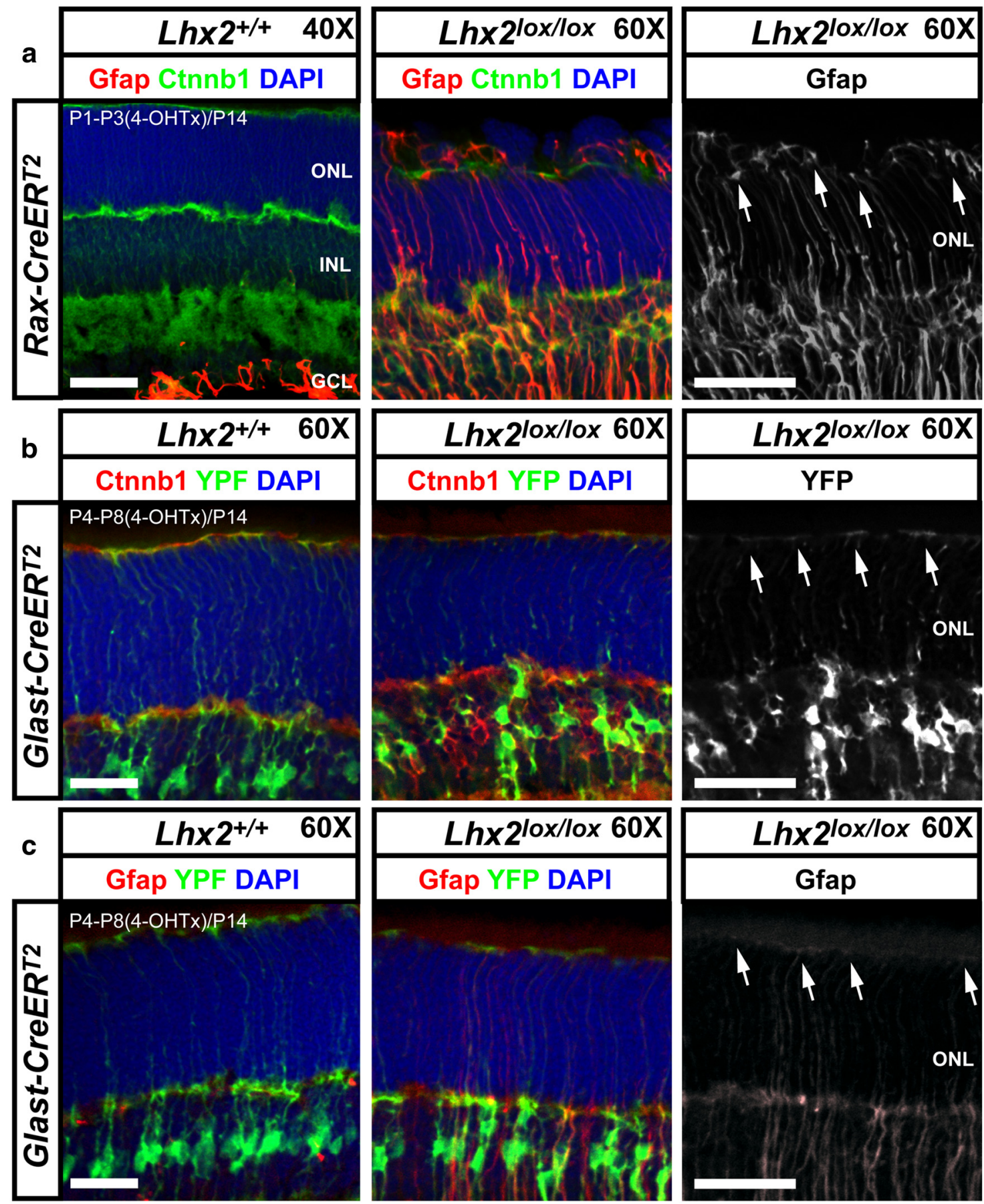

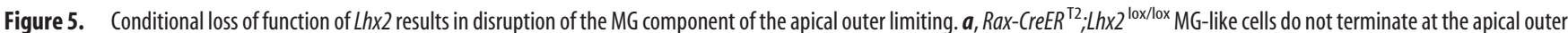
limiting membrane (white arrows) and do not colabel Ctnnb1 (also known as $\beta$-catenin). b, c, Glast-CreER ${ }^{\mathrm{T}}$;Lhx2 ${ }^{\text {lox/lox }} \mathrm{MG}$ form normal apical termini that colabel with Ctnnb1 (white arrows). 4-OHTx, 4-hydroxytamoxifen. Scale bars, $50 \mu \mathrm{m}$ (all panels).

than the dysplasia seen in the Pdgfr $\alpha$-Cre; $L h x 2^{\text {lox/lox }}$ knock-outs (Fig. 2b,d,f,h). Rax-CreER ${ }^{\mathrm{T} 2} ; \operatorname{Lh} x 2^{\mathrm{lox} / \mathrm{lox}}$ retinas also lacked a clearly defined OLM (Figs. $4 d, 5 a$ ). These results show that selective loss of $L h \times 2$ function in MG precursors results in extensive disruption of MG differentiation.

Lhx2 is required for Notch signaling and Notch-mediated Müller gliogenesis

Previous studies have shown that MG specification is regulated by Notch signaling, and is dependent on the action of the transcriptional Notch effector Hes5, and its downstream target genes
Sox8 and Sox9 (Furukawa et al., 2000; Hojo et al., 2000; Muto et al., 2009). To determine whether MG defects after $L h \times 2$ loss of function were in part due to perturbed Notch signaling, we coelectroporated three different plasmid constructs - the Notch reporter pCBFRE-GFP, pCAG-Cre, and the Cre-activated reporter construct pCALNL-DsRed-into both $L h \times 2^{+/+}$and $L h \times 2^{\text {lox/lox }}$ retinas at P0. Reporter expression was analyzed in DsRedpositive electroporated cells at P3 (Fig. $6 a, b$ ). In $L h \times 2^{+/+}$mice $75 \%$ of DsRed labeled cells demonstrated GFP expression off the pCBFRE-GFP Notch reporter (Fig. 6b). The proportion of cells displaying Notch reporter expression in $L h \times 2^{\text {lox/lox }}$ mice was sig- 

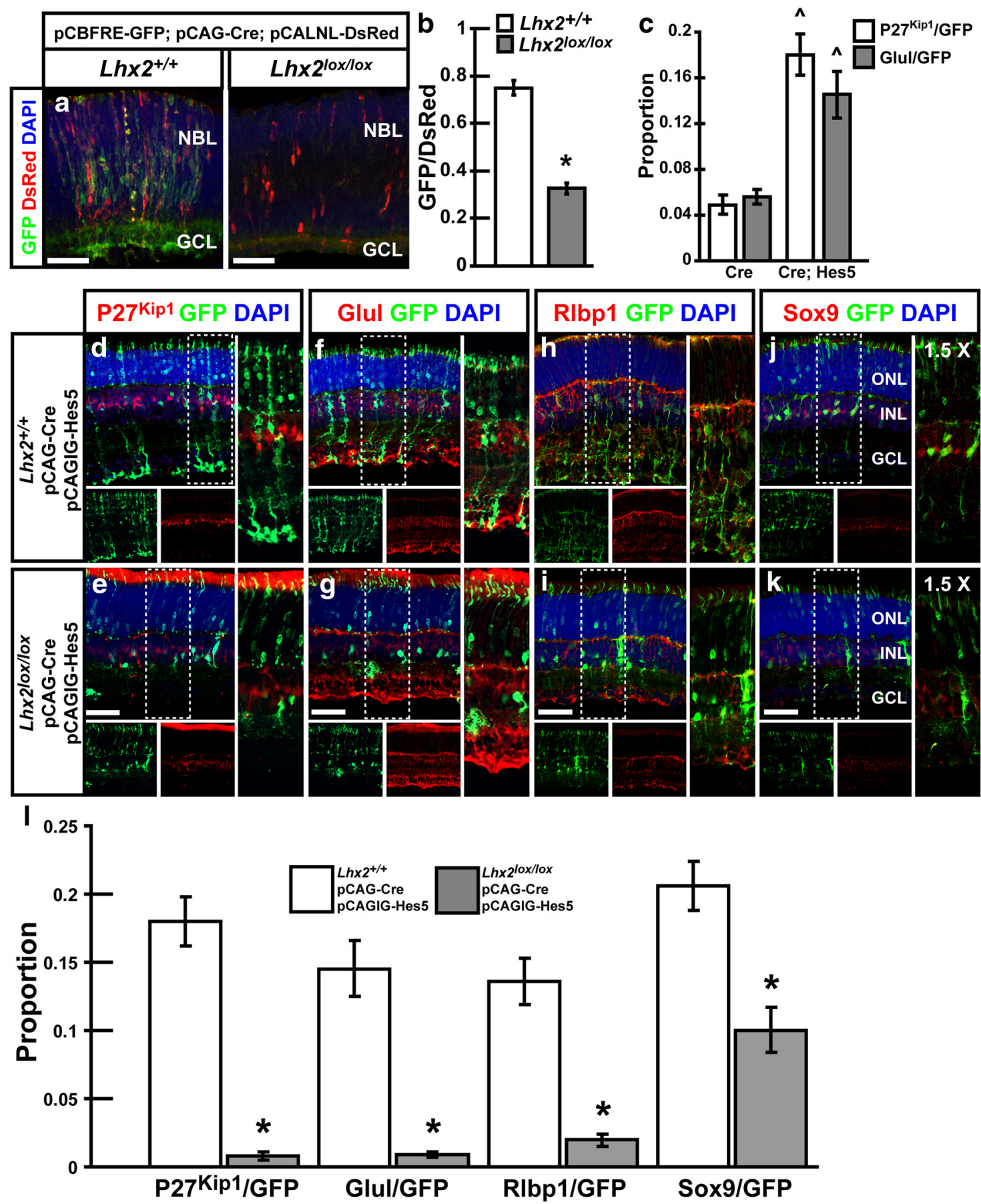

Figure 6. Lhx2 loss of function perturbs Notch signaling and blocks Hes5-mediated gliogenesis. $\boldsymbol{a}, \boldsymbol{b}$, Co-electroporation of $p$ CAG-Cre with pCBFRE-GFP at P0. Expression of the Notch reporter is significantly $(p<0.05 ; n=5)$ decreased among electroporated cells at P3 in $L h x 2^{\text {lox/lox }}$ mice. $\boldsymbol{c}, \boldsymbol{d}, \boldsymbol{f}, \boldsymbol{h}-\boldsymbol{j}, \boldsymbol{l}$, , Electroporation of Hes 5 at P0 significantly induces the formation of MG by P14 ( $p<0.05$; $n=6$ for all of p $27^{\text {Kip } 1}$; Glul; Rlbp; Sox9). $\boldsymbol{d}-I$, Electroporation of pCAG-Cre with pCAGIG-Hes5 into Lhx2 ${ }^{\text {lox/lox }}$ vs $L h x 2^{+/+}$mice shows that the effect of Hes 5 is blocked by concurrent $L h \times 2$ loss of function ( $p<0.05 ; n=6$; for all of $p 27^{\text {Kip1; }}$ Glul; Rlbp; Sox9). 1.5-fold digital enlargements without DAPI labeling are included for $\boldsymbol{d}$-k. ` Significant increase; *significant decrease. Scale bars, 50 $\mu \mathrm{m}$ (all panels).

nificantly reduced to $32 \%$. Furthermore, the cellular levels of GFP expression were substantially weaker in the $L h \times 2^{\text {lox/lox }}$ cells compared with the $L h \times 2^{+/+}$cells (Fig. $6 a$ ).

These results suggest that the loss of MG in $L h \times 2^{\text {lox/lox }}$ mice may in part result from a disruption of Notch signaling in RPCs. We next explored whether electroporation of the potently gliogenic Notch effector Hes5 (Hojo et al., 2000) was sufficient to rescue the loss of gliogenesis in $L h \times 2^{\text {lox/lox }}$ animals. Electroporation of Hes5 with Cre in wild-type retinas resulted in a dramatic overproduction of MG compared with electroporation of Cre alone (pCAG-Cre: $4.9 \%$ and $5.6 \%$ vs pCAG-Cre/-Hes5: 18\% and 15\%, P2 $7^{\mathrm{Kip} 1}$ and Glul ${ }^{+}$respectively; Fig. 6c). However, co-electroporation of Hes5 with Cre did not rescue MG development in $L h \times 2^{\text {lox/lox }}$ mice (Fig. $6 d-k$ ). The proportion of P27 ${ }^{\mathrm{Kip} 1}$, Glul, and Rlbp1positive MG generated after electroporation of Hes5 and Cre into $L h \times 2^{\text {lox/lox }}$ mice was nearly identical to that after electroporation of Cre alone (Figs. 3i, 6l). Though significantly 
reduced, Sox9 expression remained elevated in $L h \times 2^{\text {lox/lox }}$ mice after Hes 5 and Cre co-electroporation. The proportion of Sox9-positive cells dropped from $20.6 \%$ in control mice to $10 \%$, but these data suggest that Hes 5 may be sufficient to activate Sox9 in the absence of Lhx2 to a limited extent. These results demonstrate that Hes5-induced Müller gliogenesis requires $L h \times 2$.

To determine whether expression of Notch pathway genes and Notch pathway regulators were disrupted upon $L h x 2$ loss of function, we performed RNA-Seq on P0.5 Pdgfr $\alpha$-Cre;Lhx $2^{\text {lox/lox }}$ and control $L h \times 2^{\text {lox/lox }}$ retinas (Fig. 7). The full dataset including raw data has been deposited to the Gene Expression Omnibus (GEO) repository of NCBI (series accession \# GSE75889). Analysis of RNA-Seq data revealed a high proportion of RPC and MG-enriched genes among transcripts downregulated after loss of $L h \times 2$, whereas genes associated with neuronal populations were enriched among upregulated transcripts (Fig. 7a,b). We also observed a significant upregulation of hypothalamic-expressed genes after $L h \times 2$ loss of function, replicating results previously observed (Roy et al., 2013). Analysis of Gene Ontology (GO) terms identified the Notch pathway as the signaling pathway that is most highly enriched among genes downregulated by loss of $\operatorname{Lh} \times 2$ (Fig. $7 c$ ).

We selected Notch pathway genes that demonstrated decreased expression by RNA-Seq and then performed a combination of qRT-PCR and in situ hybridization to validate the results (Fig. 8, Table 1). We observed a significant reduction in expression of Notch pathway genes including Notch1 (Fig. $8 a, c$, Table 1); the Notch ligands Dll1 and Dll3 (Fig. 8a,d,e, Table 1); the gliogenic Notch effector genes Hes1, Hes5, Id1, and Sox8 (Fig. $8 a, f, g$, Table 1); and the Müller-gliogenic factor Rax (Fig. $8 a, h$, Table 1). We likewise observed a significant reduction in the expression of progenitor-specific genes such as Vsx2 and Fgf15 (Fig. 8a,i,j, Table 1). A decrease in the expression of early-onset glial markers, such as Crym, Spon1, and Car2, was also observed (Table 1). Finally, we confirmed that the hypothalamic and thalamic eminence-enriched genes Sfrp2, Otp, and Lhx5 showed increased expression (Fig. $8 k-m$ ). In situ hybridization confirmed that altered expression of all of these genes corresponded to regions in which $L h \times 2$ loss of expression was observed (Fig. $8 b-m$ ).

\section{Lhx2 regulates transcription of Notch pathway genes and other genes required for progenitor proliferation and gliogenesis directly}

The previously described data imply that Lhx 2 is necessary for activating expression of Notch pathway components and other MG-expressed genes. We performed ChIP-qPCR, and investigated whether Lhx2 bound directly candidate cis-regulatory sequences located upstream of genes with expression that was reduced in Lhx2 knock-outs (Hu et al., 2009; Nelson et al., 2011), which we identified as active enhancers by conducting ChIPqPCR for H3K27Ac (Creyghton et al., 2010; Fig. 9a, $a^{\prime}$ ).

At P2, when the vast majority of Lhx 2 is expressed in RPCs, we observed that Lhx2 was directly bound to cis-regulatory regions associated with the progenitor expressed Müller gliogenic homeodomain factor Rax in retinas (Fig. 9b). Lhx2 also bound to the gliogenic bHLH factor Hes5 and the early glial markers Slc1a3 and Car2 (Blackshaw et al., 2004) directly at this time point (Fig. 9b). We also identified direct Lhx2 binding to regulatory regions of the RPC-enriched genes $V s x 2$ and Fgf15 at P2 (Fig. 9c). However, Lhx2 was not bound to nearby sequences that lacked predicted Lhx2 binding sites.

We next investigated whether Lhx2 was bound differentially to the identified target regions of interest as MG development proceeded. From P7 onward, the majority of Lhx2-positive cells are MG rather than RPCs (Fig. $1 h-j, m-o$ ). We performed ChIPqPCR at P8 and found that, for all sequences, the relative level of Lhx2 binding was reduced relative to $\mathrm{P} 2$. This was is consistent with the sevenfold decrease in the total fraction of Lhx2expressing retinal cells, RPCs, or MG at P8 relative to P2 (Young, 1985; Fig. 9d). Surprisingly, binding of Lhx2 to regulatory regions of the gliogenic transcription factor Hes5 and the MG-specific genes Slc1a3 and Car2 showed decreases between P2 and P8 much like that observed for enhancers associated with the RPCspecific genes $V s x 2$ and $F g f 15$ (Fig. 9b,c). These results imply that Lhx2 may be required for activation of MG-specific genes upon 


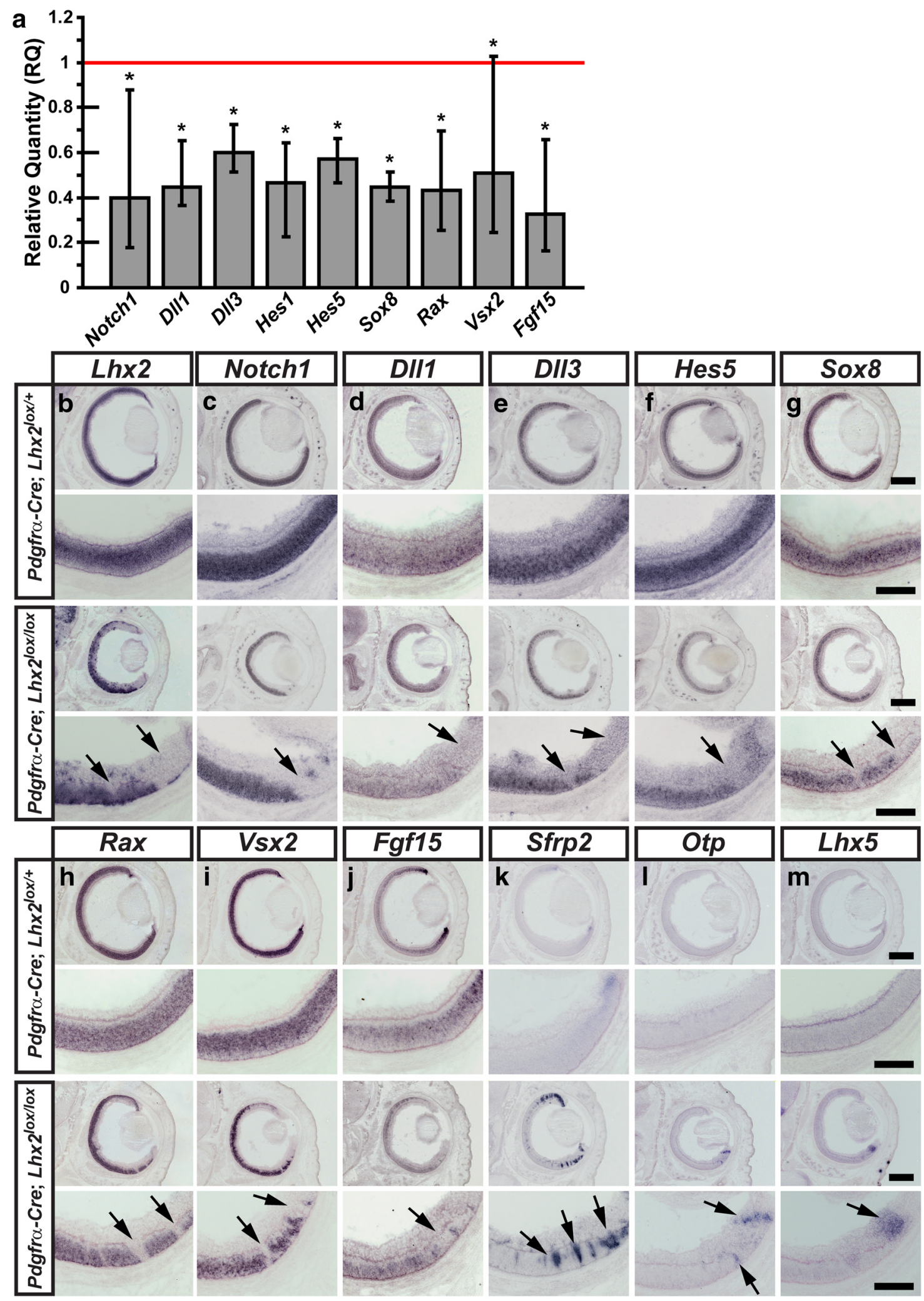

Figure 8. Expression of Notch pathway, gliogenic, RPC-enriched, and hypothalamic-enriched genes in the $L h x 2$-deficient retina. $a, q R T-P C R$ analysis of P0.5 Pdgfr $\alpha$-Cre; $L$ hx $2^{\text {lox/lox }}$ and control $L h \times 2^{\text {lox/lox }}$ mice. Bars on the graph represent the mean relative quantity $(R Q)$ of expression of the gene target, with error bars representing the minimum and maximum value of $\mathrm{RQ}$ observed in the study. ${ }^{*}$ Statistical significance. $\boldsymbol{b}-\boldsymbol{m}$, In situ hybridization performed on PO.5 Pdgfr $\alpha$-Cre; $L$ hx $2^{\text {lox/lox }}$ and control Lhx $2^{\text {lox/lox }}$ mice. Arrows indicate regions of loss or gain

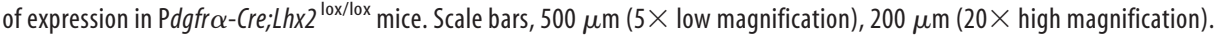


Table 1. Selected RNA-Seq data from PO retinas

\begin{tabular}{llccl}
\hline Gene & Function & Control & cK0* & Ratio \\
\hline Notch1 & Notch pathway & 218.2 & 184.8 & 0.85 \\
DIl1 & Notch pathway & 61.8 & 46.2 & 0.74 \\
DIl3 & Notch pathway & 34.1 & 26.4 & 0.77 \\
Hes1 & Notch pathway & 55.6 & 25.6 & 0.46 \\
Hes5 & Notch pathway & 83 & 41.9 & 0.5 \\
Id1 & Gliogenic factor & 60.4 & 15 & 0.25 \\
Sox8 & Gliogenic factor & 78.4 & 38.2 & 0.49 \\
Rax & Gliogenic factor & 123.8 & 39.4 & 0.32 \\
Car2 & Early glial marker & 79.4 & 47.8 & 0.6 \\
Crym & Early glial marker & 79 & 24.3 & 0.31 \\
Spon1 & Early glial marker & 53.3 & 18.5 & 0.35 \\
Vsx2 & Pluripotency/proliferation & 338.5 & 143.2 & 0.42 \\
Fgf15 & Pluripotency/proliferation & 75.1 & 24.7 & 0.33 \\
\hline
\end{tabular}

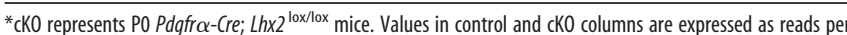
kilobase of transcript per million mapped reads (RPKM).

initiation of gliogenesis, but may not be necessary to maintain their expression in mature glia.

\section{Discussion}

We have identified the LIM homeodomain transcription factor Lhx2 as an essential regulator of Müller gliogenesis. Loss of function of $L h \times 2$ in $P d g f r \alpha-C r e ; L h \times 2^{\text {lox/lox }}$ knock-out mice resulted in decreased RPC proliferation and loss of expression of the MG markers P27 ${ }^{\text {Kip1 }}$, Glul, Rlbp1, and Sox9. Loss of MG was supported by R26-stop-EYFP labeling, which confirmed a dramatic reduction in radial MG. Electroporation of pCAG-Cre into P0 retinas also showed that the development of $\mathrm{MG}$ was disrupted selectively upon postnatal loss of function of $L h \times 2$. By contrasting the phenotypes generated by temporally controlled conditional loss of function of $L h \times 2$ in differentiated MG (Glast-CreER ${ }^{\mathrm{T} 2}$; Lhx $2^{\text {lox/lox }}, \mathrm{P} 4-\mathrm{P} 84$-OHT induction) and MG precursors (Rax$\mathrm{CreER}^{\mathrm{T} 2}$; Lh $x 2^{\text {lox/lox }}, \mathrm{P} 1-\mathrm{P} 34$-OHT induction), we show that $L h \times 2$ is required for terminal differentiation of $M G$, expression of multiple MG-specific markers, development of characteristic apical MG structures, and active suppression of reactive gliosis. Finally, we demonstrate that $L h \times 2$ loss of function results in the downregulation of Notch signaling and decreased expression of Notch-pathway-dependent gliogenic effector genes. Lhx2 loss of function was sufficient to block the formation of differentiated MG induced by the potently gliogenic Notch effector Hes5.

The functional role played by $L h \times 2$ in the development of CNS glia is complex and context dependent. Previous work demonstrated that loss of $L h \times 2$ in hippocampal radial glial progenitors resulted in cell cycle dropout and premature astrocyte formation (Subramanian et al., 2011). The same study showed that Lhx2 misexpression blocks astrogliogenesis and can override the proastroglial effects of both Notch activation and misexpression of Nfia. Conversely, $L h \times 2$ is essential for development of the cortical glial wedge (GW) (Chinn et al., 2015). Here, loss of function of $L h \times 2$ in neocortical radial glial progenitor cells near the onset of cortical neurogenesis resulted in a cell cycle exit similar to that seen in the hippocampus, but with premature formation of neurons and a loss of the stellate astrocytes that comprise the GW.

Both studies strongly indicate a shared and essential role for Lhx2 among radial glial cell populations. In the hippocampus and neocortex, radial glial cells function as progenitors that give rise to neurons and astrocytes (Subramanian et al., 2011). Intriguingly, three specialized adult radial glial populations have also been identified: hypothalamic tanycytes, cerebellar Bergmann glia, and retinal MG (Sild and Ruthazer, 2011). Our study shows that $L h x 2$ is essential for the development of retinal MG. By using multiple temporal and cell-specific knock-out models, we have demonstrated a requirement for $L h \times 2$ function at every stage of MG development. Pdgfr $\alpha$-Cre-mediated loss of function in retinal progenitor cells demonstrated that $L h \times 2$ is required for the proliferation and expansion of gliocompetent progenitors. Rax$\mathrm{CreER}^{\mathrm{T} 2}$-mediated loss of function in MG precursors from $\mathrm{P} 1$ demonstrated that $L h \times 2$ was required for differentiation of MG and development of specialized MG histological features. Glast$\mathrm{CreER}^{\mathrm{T} 2}$-mediated loss of function in newly differentiated MG from P4 demonstrated that $L h \times 2$ is required for the active suppression of reactive gliosis, confirming previously published reports (de Melo et al., 2012). The functional requirement for $L h \times 2$ in the development of adult radial glial populations may be universal. Hypothalamic tanycytes also express Lhx2 and conditional inactivation of $L h \times 2$ produces a variety of defects during tanycyte differentiation. These include the loss of expression of tanycyte-specific genes such as Rax and Gpr50, the ectopic expression of Foxj1, and, ultimately, the formation of dysmorphic multiciliated tanycytes (Salvatierra et al., 2014).

We have shown that $L h \times 2$ function is necessary for Notch signaling in the developing retina and may activate a wide array of Notch pathway genes. Knocking out $L h \times 2$ in RPCs resulted in a corresponding loss of RNA expression of both Notch1 and the gliogenic Notch pathway transcriptional effectors Id1, Sox8, and Hes5 by P0.5. Co-electroporation of pCAG-Cre with the pCBFRE-GFP Notch signaling reporter into $L h \times 2^{\text {loxl/lox }}$ animals also revealed a rapid loss of Notch signaling. This was demonstrated by a reduction in the number of electroporated cells showing Notch reporter activity and by the qualitative decrease of GFP signal among those few cells in which Notch reporter activity could still be detected.

Notch signaling is an essential regulator of glial development in the CNS. Multiple studies have demonstrated that temporally controlled loss of function of retinal Notch expression results in progenitor dropout, compromised neurogenesis, and a loss of gliogenesis. The specific neurogenic deficits that result vary with both the timing of the loss of function and the animal model in which it was investigated, but the negative impact on MG development appears universal. Generally, early embryonic loss of Notch function results in an overproduction of cone photoreceptors and retinal ganglion cells at the expense of all other cell types (Austin et al., 1995; Maurer et al., 2014), whereas late embryonic or early postnatal loss of function yields rod photoreceptors at the expense of bipolar interneurons and MG (Furukawa et al., 2000; Hojo et al., 2000; Satow et al., 2001; Jadhav et al., 2009; Nelson et al., 2011; Mizeracka et al., 2013). These results parallel, but do not precisely phenocopy, the effects of selective loss of $L h \times 2$ in earlystage RPCs (Gordon et al., 2013) and late-stage RPCs, as reported here. This could be because loss of function of $L h \times 2$ dramatically reduces Notch signaling in late-stage RPCs, but may not eliminate it altogether. After electroporation of Cre into $L h \times 2^{\text {lox/lox }}$ retinas at $\mathrm{P} 0$, we saw a result that parallels late Notch disruption, with MG selectively lost. Bipolar cell numbers were also reduced, although counts did not reach statistical significance, whereas a trend toward increased rod photoreceptor number was also seen.

Although Lhx2 activation and maintenance of Notch signaling is essential for appropriate MG development, we found that Lhx2 may not regulate MG development exclusively via Notch activation. The downstream bHLH Notch effector Hes5 is a potent inducer of MG development in the mouse retina (Hojo et al., 2000). We confirmed that electroporation of Hes5 in Lhx $2^{+/+}$ retinas was sufficient to promote a nearly fourfold increase in 
a

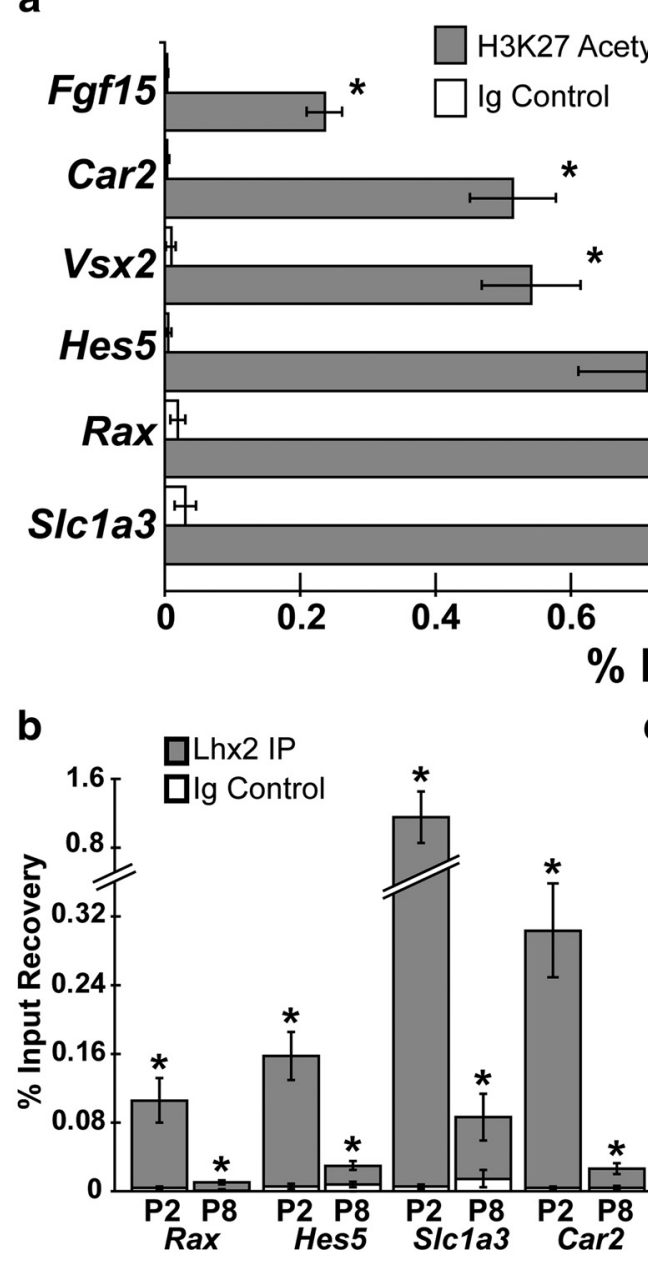

a'

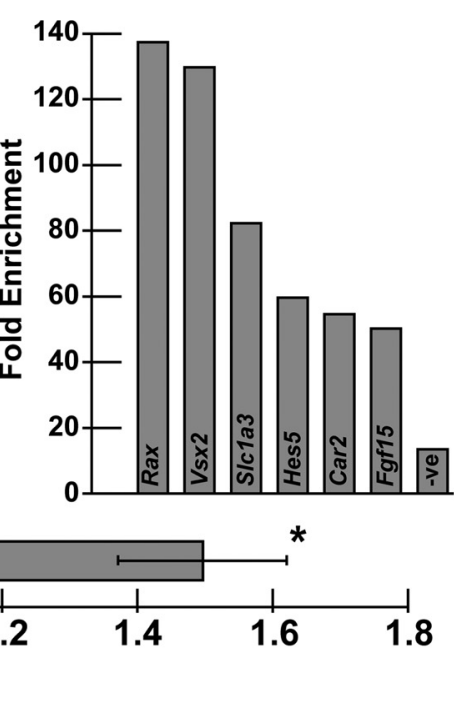

c

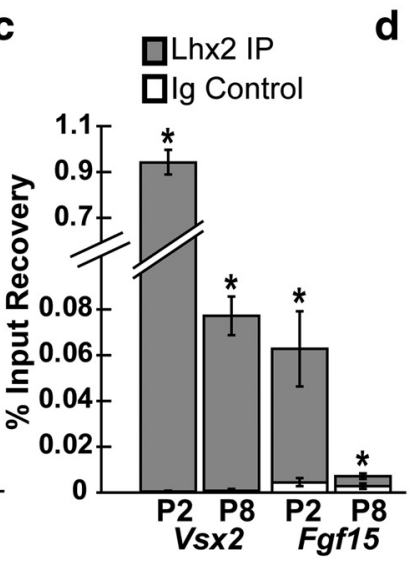

d

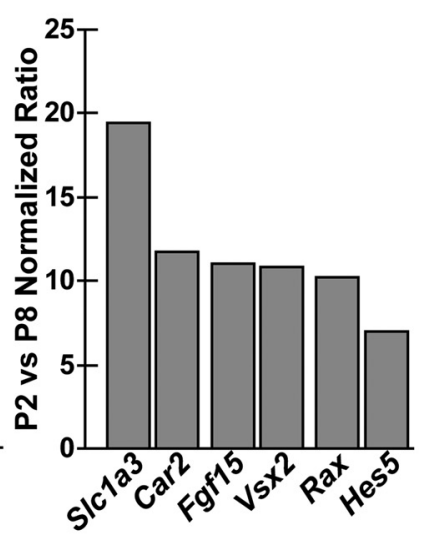

Figure 9. ChIP analysis of Lhx2 in the developing retina. $\boldsymbol{a}$, Relative percentages of input recovery for the H3K27Ac and isotype control fractions in the retina at P2. Bars represent SEM ( $n=3$, minimum degrees of freedom $=9$ ). $\boldsymbol{a}^{\prime}$, Fold enrichment for the H3K27Acetylated IP on indicated promoter sites. The target regions are all significantly enriched $(p<0.0001)$ by $t$ test assuming unequal variances between Lhx2 ChIP and Ig control fractions. $\boldsymbol{b}, \boldsymbol{c}$, Lhx2 ChIP was performed on retinal tissue collected at P2 and P8. Graphs show the mean percentages of input recovery for the immunoprecipitated fractions and the isotype controls compared by two-tailed $t$ test. *Statistical significance $(p<0.05)$. Error bars represent the SE $(n>=3)$. Target regions were inferred from a computational analysis of $\mathrm{L}$ X 2 consensus sequences near the genes of interest. $d$, Ratio of $L$ hx 2 occupancy at target promoters, P2 versus P8. P2 and P8 occupancy levels were normalized to isotypic controls before ratio calculation.

MG. However, electroporation of Hes5 with pCAG-Cre into $L h \times 2^{\text {lox/lox }}$ retinas was insufficient to rescue the loss of MG resulting from $L h \times 2$ loss of function. Lhx2 may thus cooperate directly with Hes5 to activate expression of the genes necessary for MG differentiation and function. In such a model, the two factors may operate in a common transcriptional protein complex or, conversely, may bind common gene targets at distinct regulatory loci. Alternatively, Lhx2 may be required for the activation of a distinct set of Hes5-independent gene targets essential for the development of MG. In either model, Hes5 is insufficient to activate a Müller gliogenic program in the absence of Lhx2.

Currently, interest in MG is high due to their intrinsic capacity for cellular reprogramming in response to retinal lesions (Goldman, 2014; Lenkowski and Raymond, 2014). In teleost fish, MG dedifferentiate and proliferate to produce RPCs that regenerate the retina after injury (Bernardos et al., 2007). The regenerative potential of mammalian MG in situ is extremely limited compared with fish, but mammalian MG can reactivate expression of RPC-specific genes and proliferate in response to injury (Osakada et al., 2007; Karl et al., 2008). Strategies that target MG in regenerative therapies must overcome MG quiescence. We show here that $L h \times 2$ is essential for the differentiation of RPCs into mature $M G$ and that expression of Lhx2 is maintained in mature MG. It is possible that the developmental mechanism by which $L h x 2$ promotes MG differentiation must be reversed for MG to become proliferative and contribute to regeneration. Currently, the mechanistic role for $\operatorname{Lh} x 2$ in the regenerating fish retina is unknown. However, our demonstration that $\operatorname{Lh} \times 2$ is required for Notch signaling during development is intriguing. Notch signaling stabilizes MG identity in postmitotic precursor cells in the mouse (Nelson et al., 2011; Mizeracka et al., 2013). Furthermore, blocking Notch signaling in both chick and zebrafish enhances the proliferative and regenerative capacity of progenitor cells generated by MG (Hayes et al., 2007; Conner et al., 2014). Lhx2-mediated activation of Notch signaling may therefore contribute to $M G$ quiescence.

We have demonstrated previously that conditional loss of function of $L h \times 2$ in adult MG was sufficient to trigger hypertrophic reactive gliosis and that $L h x 2$ was required for injuryinduced expression of neuroprotective factors in these same MG. We show in this work that $\operatorname{Lh} x 2$ is required for the proliferation of 
gliocompetent progenitors. The regulation of the cell cycle by Lhx2 has also been noted previously in neurogenic RPCs of the retina and in cortical progenitors (Chou and O'Leary, 2013; Gordon et al., 2013). Finally, we show that Lhx2 is necessary for normal differentiation of MG. These diverse, temporally dynamic, and context-dependent functions of $L h \times 2$ are likely mediated by changes in both Lhx2 binding patterns and cofactor usage. Identifying these biochemical mechanisms of action will be the next major challenge in understanding the role played by Lhx2 in MG development and function in the healthy and diseased retina.

\section{References}

Anders S, Pyl PT, Huber W (2015) HTSeq: a python framework to work with high-throughput sequencing data. Bioinformatics 31:166-169. CrossRef Medline

Austin CP, Feldman DE, Ida JA Jr, Cepko CL (1995) Vertebrate retinal ganglion cells are selected from competent progenitors by the action of Notch. Development 121:3637-3650. Medline

Balasubramanian R, Bui A, Ding Q, Gan L (2014) Expression of LIMhomeodomain transcription factors in the developing and mature mouse retina. Gene Expr Patterns 14:1-8. CrossRef Medline

Bernardos RL, Barthel LK, Meyers JR, Raymond PA (2007) Late-stage neuronal progenitors in the retina are radial Müller glia that function as retinal stem cells. J Neurosci 27:7028-7040. CrossRef Medline

Blackshaw S, Fraioli RE, Furukawa T, Cepko CL (2001) Comprehensive analysis of photoreceptor gene expression and the identification of candidate retinal disease genes. Cell 107:579-589. CrossRef Medline

Blackshaw S, Harpavat S, Trimarchi J, Cai L, Huang H, Kuo WP, Weber G, Lee K, Fraioli RE, Cho SH, Yung R, Asch E, Ohno-Machado L, Wong WH, Cepko CL (2004) Genomic analysis of mouse retinal development. PLoS Biol 2:E247. CrossRef Medline

Chinn GA, Hirokawa KE, Chuang TM, Urbina C, Patel F, Fong J, Funatsu N, Monuki ES (2015) Agenesis of the corpus callosum due to defective glial wedge formation in Lhx2 mutant mice. Cereb Cortex 25:2707-2718. CrossRef Medline

Chou SJ, O'Leary DD (2013) Role for Lhx2 in corticogenesis through regulation of progenitor differentiation. Mol Cell Neurosci 56:1-9. CrossRef Medline

Chou SJ, Perez-Garcia CG, Kroll TT, O’Leary DD (2009) Lhx2 specifies regional fate in Emx1 lineage of telencephalic progenitors generating cerebral cortex. Nat Neurosci 12:1381-1389. CrossRef Medline

Conner C, Ackerman KM, Lahne M, Hobgood JS, Hyde DR (2014) Repressing notch signaling and expressing TNFalpha are sufficient to mimic retinal regeneration by inducing muller glial proliferation to generate committed progenitor cells. J Neurosci 34:14403-14419. CrossRef Medline

Creyghton MP, Cheng AW, Welstead GG, Kooistra T, Carey BW, Steine EJ, Hanna J, Lodato MA, Frampton GM, Sharp PA, Boyer LA, Young RA, Jaenisch R (2010) Histone H3K27Ac separates active from poised enhancers and predicts developmental state. Proc Natl Acad Sci U S A 107: 21931-21936. CrossRef Medline

de Melo J, Blackshaw S (2011) In vivo electroporation of developing mouse retina. J Vis Exp 52:pii:2847. CrossRef Medline

de Melo J, Miki K, Rattner A, Smallwood P, Zibetti C, Hirokawa K, Monuki ES, Campochiaro PA, Blackshaw S (2012) Injury-independent induction of reactive gliosis in retina by loss of function of the LIM homeodomain transcription factor Lhx2. Proc Natl Acad Sci U S A 109:4657-4662. CrossRef Medline

Dobin A, Davis CA, Schlesinger F, Drenkow J, Zaleski C, Jha S, Batut P, Chaisson M, Gingeras TR (2013) STAR: Ultrafast universal RNA-seq aligner. Bioinformatics 29:15-21. CrossRef Medline

Folgueras AR, Guo X, Pasolli HA, Stokes N, Polak L, Zheng D, Fuchs E (2013) Architectural niche organization by LHX2 is linked to hair follicle stem cell function. Cell Stem Cell 13:314-327. CrossRef Medline

Furukawa T, Mukherjee S, Bao ZZ, Morrow EM, Cepko CL (2000) Rax, Hes1, and notch 1 promote the formation of muller glia by postnatal retinal progenitor cells. Neuron 26:383-394. CrossRef Medline

Gallo V, Deneen B (2014) Glial development: the crossroads of regeneration and repair in the CNS. Neuron 83:283-308. CrossRef Medline
Goldman D (2014) Müller glial cell reprogramming and retina regeneration. Nat Rev Neurosci 15:431-442. CrossRef Medline

Gordon PJ, Yun S, Clark AM, Monuki ES, Murtaugh LC, Levine EM (2013) Lhx2 balances progenitor maintenance with neurogenic output and promotes competence state progression in the developing retina. J Neurosci 33:12197-12207. CrossRef Medline

Hayes S, Nelson BR, Buckingham B, Reh TA (2007) Notch signaling regulates regeneration in the avian retina. Dev Biol 312:300-311. CrossRef Medline

Henrique D, Hirsinger E, Adam J, Le Roux I, Pourquié O, Ish-Horowicz D, Lewis J (1997) Maintenance of neuroepithelial progenitor cells by deltanotch signalling in the embryonic chick retina. Curr Biol 7:661-670. Medline

Hojo M, Ohtsuka T, Hashimoto N, Gradwohl G, Guillemot F, Kageyama R (2000) Glial cell fate specification modulated by the bHLH gene Hes5 in mouse retina. Development 127:2515-2522. Medline

Hu S, Xie Z, Onishi A, Yu X, Jiang L, Lin J, Rho HS, Woodard C, Wang H, Jeong JS, Long S, He X, Wade H, Blackshaw S, Qian J, Zhu H (2009) Profiling the human protein-DNA interactome reveals ERK2 as a transcriptional repressor of interferon signaling. Cell 139:610-622. CrossRef Medline

Imayoshi I, Kageyama R (2014) bHLH factors in self-renewal, multipotency, and fate choice of neural progenitor cells. Neuron 82:9-23. CrossRef Medline

Jadhav AP, Cho SH, Cepko CL (2006) Notch activity permits retinal cells to progress through multiple progenitor states and acquire a stem cell property. Proc Natl Acad Sci U S A 103:18998-19003. CrossRef Medline

Jadhav AP, Roesch K, Cepko CL (2009) Development and neurogenic potential of Müller glial cells in the vertebrate retina. Prog Retin Eye Res 28:249-262. CrossRef Medline

Karl MO, Hayes S, Nelson BR, Tan K, Buckingham B, Reh TA (2008) Stimulation of neural regeneration in the mouse retina. Proc Natl Acad Sci U S A 105:19508-19513. CrossRef Medline

Kopan R, Ilagan MX (2009) The canonical notch signaling pathway: Unfolding the activation mechanism. Cell 137:216-233. CrossRef Medline

Lenkowski JR, Raymond PA (2014) Müller glia: Stem cells for generation and regeneration of retinal neurons in teleost fish. Prog Retin Eye Res 40:94-123. CrossRef Medline

Macosko EZ, Basu A, Satija R, Nemesh J, Shekhar K, Goldman M, Tirosh I, Bialas AR, Kamitaki N, Martersteck EM, Trombetta JJ, Weitz DA, Sanes JR, Shalek AK, Regev A, McCarroll SA (2015) Highly parallel genomewide expression profiling of individual cells using nanoliter droplets. Cell 161:1202-1214. CrossRef Medline

Mangale VS, Hirokawa KE, Satyaki PR, Gokulchandran N, Chikbire S, Subramanian L, Shetty AS, Martynoga B, Paul J, Mai MV, Li Y, Flanagan LA, Tole S, Monuki ES (2008) Lhx2 selector activity specifies cortical identity and suppresses hippocampal organizer fate. Science 319:304-309. CrossRef Medline

Matsuda T, Cepko CL (2007) Controlled expression of transgenes introduced by in vivo electroporation. Proc Natl Acad Sci U S A 104:10271032. CrossRef Medline

Maurer KA, Riesenberg AN, Brown NL (2014) Notch signaling differentially regulates Atoh7 and Neurog2 in the distal mouse retina. Development 141:3243-3254. CrossRef Medline

McConnell SK (1995) Constructing the cerebral cortex: Neurogenesis and fate determination. Neuron 15:761-768. CrossRef Medline

Mizeracka K, DeMaso CR, Cepko CL (2013) Notch1 is required in newly postmitotic cells to inhibit the rod photoreceptor fate. Development 140: 3188-3197. CrossRef Medline

Mizutani K, Yoon K, Dang L, Tokunaga A, Gaiano N (2007) Differential notch signaling distinguishes neural stem cells from intermediate progenitors. Nature 449:351-355. CrossRef Medline

Morrison SJ, Perez SE, Qiao Z, Verdi JM, Hicks C, Weinmaster G, Anderson DJ (2000) Transient Notch activation initiates an irreversible switch from neurogenesis to gliogenesis by neural crest stem cells. Cell 101: 499-510. CrossRef Medline

Muto A, Iida A, Satoh S, Watanabe S (2009) The group E sox genes Sox8 and Sox 9 are regulated by Notch signaling and are required for Müller glial cell development in mouse retina. Exp Eye Res 89:549-558. CrossRef Medline

Nelson BR, Ueki Y, Reardon S, Karl MO, Georgi S, Hartman BH, Lamba DA, Reh TA (2011) Genome-wide analysis of Müller glial differentiation re- 
veals a requirement for notch signaling in postmitotic cells to maintain the glial fate. PLoS One 6:e22817. CrossRef Medline

Okano H, Temple S (2009) Cell types to order: Temporal specification of CNS stem cells. Curr Opin Neurobiol 19:112-119. CrossRef Medline

Osakada F, Ooto S, Akagi T, Mandai M, Akaike A, Takahashi M (2007) Wnt signaling promotes regeneration in the retina of adult mammals. J Neurosci 27:4210-4219. CrossRef Medline

Pak T, Yoo S, Miranda-Angulo AL, Wang H, Blackshaw S (2014) RaxCreERT2 knock-in mice: A tool for selective and conditional gene deletion in progenitor cells and radial glia of the retina and hypothalamus. PLoS One 9:e90381. CrossRef Medline

Porter FD, Drago J, Xu Y, Cheema SS, Wassif C, Huang SP, Lee E, Grinberg A, Massalas JS, Bodine D, Alt F, Westphal H (1997) Lhx2, a LIM homeobox gene, is required for eye, forebrain, and definitive erythrocyte development. Development 124:2935-2944. Medline

Rattner A, Yu H, Williams J, Smallwood PM, Nathans J (2013) Endothelin-2 signaling in the neural retina promotes the endothelial tip cell state and inhibits angiogenesis. Proc Natl Acad Sci U S A 110: E3830-E3839. CrossRef Medline

Reichenbach A (1989) Attempt to classify glial cells by means of their process specialization using the rabbit retinal Müller cell as an example of cytotopographic specialization of glial cells. Glia 2:250-259. CrossRef Medline

Robinson MD, McCarthy DJ, Smyth GK (2010) edgeR: A bioconductor package for differential expression analysis of digital gene expression data. Bioinformatics 26:139-140. CrossRef Medline

Roesch K, Jadhav AP, Trimarchi JM, Stadler MB, Roska B, Sun BB, Cepko CL (2008) The transcriptome of retinal Müller glial cells. J Comp Neurol 509:225-238. CrossRef Medline

Roy A, de Melo J, Chaturvedi D, Thein T, Cabrera-Socorro A, Houart C, Meyer G, Blackshaw S, Tole S (2013) LHX2 is necessary for the maintenance of optic identity and for the progression of optic morphogenesis. J Neurosci 33:6877-6884. CrossRef Medline

Roy A, Gonzalez-Gomez M, Pierani A, Meyer G, Tole S (2014) Lhx2 regulates the development of the forebrain hem system. Cereb Cortex 24: 1361-1372. CrossRef Medline

Salvatierra J, Lee DA, Zibetti C, Duran-Moreno M, Yoo S, Newman EA, Wang H, Bedont JL, de Melo J, Miranda-Angulo AL, Gil-Perotin S, Garcia-
Verdugo JM, Blackshaw S (2014) The LIM homeodomain factor Lhx2 is required for hypothalamic tanycyte specification and differentiation. J Neurosci 34:16809-16820. CrossRef Medline

Satow T, Bae SK, Inoue T, Inoue C, Miyoshi G, Tomita K, Bessho Y, Hashimoto N, Kageyama R (2001) The basic helix-loop-helix gene hesr2 promotes gliogenesis in mouse retina. J Neurosci 21:1265-1273. Medline

Shang Y, Hu X, DiRenzo J, Lazar MA, Brown M (2000) Cofactor dynamics and sufficiency in estrogen receptor-regulated transcription. Cell 103: 843-852. CrossRef Medline

Shetty AS, Godbole G, Maheshwari U, Padmanabhan H, Chaudhary R, Muralidharan B, Hou PS, Monuki ES, Kuo HC, Rema V, Tole S (2013) Lhx2 regulates a cortex-specific mechanism for barrel formation. Proc Natl Acad Sci U S A 110:E4913-E4921. CrossRef Medline

Shimogori T, Lee DA, Miranda-Angulo A, Yang Y, Wang H, Jiang L, Yoshida AC, Kataoka A, Mashiko H, Avetisyan M, Qi L, Qian J, Blackshaw S (2010) A genomic atlas of mouse hypothalamic development. Nat Neurosci 13:767-775. CrossRef Medline

Siegert S, Cabuy E, Scherf BG, Kohler H, Panda S, Le YZ, Fehling HJ, Gaidatzis D, Stadler MB, Roska B (2012) Transcriptional code and disease map for adult retinal cell types. Nat Neurosci 15:487-495, S1-S2. CrossRef Medline

Sild M, Ruthazer ES (2011) Radial glia: Progenitor, pathway, and partner. Neuroscientist 17:288-302. CrossRef Medline

Stiemke MM, Hollyfield JG (1995) Cell birthdays in Xenopus laevis retina. Differentiation 58:189-193. CrossRef Medline

Subramanian L, Sarkar A, Shetty AS, Muralidharan B, Padmanabhan H, Piper M, Monuki ES, Bach I, Gronostajski RM, Richards LJ, Tole S (2011) Transcription factor Lhx2 is necessary and sufficient to suppress astrogliogenesis and promote neurogenesis in the developing hippocampus. Proc Natl Acad Sci U S A 108:E265-E274. CrossRef Medline

Turner DL, Cepko CL (1987) A common progenitor for neurons and glia persists in rat retina late in development. Nature 328:131-136. CrossRef Medline

Wang S, Barres BA (2000) Up a notch: Instructing gliogenesis. Neuron 27: 197-200. CrossRef Medline

Young RW (1985) Cell differentiation in the retina of the mouse. Anat Rec 212:199-205. CrossRef Medline 